Review

\title{
Climate Strategic Soil Management
}

\section{Rattan Lal}

Carbon Management and Sequestration Center, The Ohio State University, 210 Kottman Hall, 2021 Coffey Rd., Columbus, OH 43210, USA

* Author to whom correspondence should be addressed; E-Mail: lal.1@ osu.edu; Tel.: +1-614-292-9069.

Received: 9 September 2013; in revised form: 11 December 2013 / Accepted: 14 December 2013 / Published: 13 February 2014

\begin{abstract}
The complex and strong link between soil degradation, climate change and food insecurity is a global challenge. Sustainable agricultural systems must be integral to any agenda to address climate change and variability, improve renewable fresh water supply and quality, restore degraded soils and ecosystems and advance food security. These challenges are being exacerbated by increasing population and decreasing per capita arable land area and renewable fresh water supply, the increasing frequency of extreme events, the decreasing resilience of agroecosystems, an increasing income and affluent lifestyle with growing preference towards meat-based diet and a decreasing soil quality and use efficiency of inputs. Reversing these downward spirals implies the implementation of proven technologies, such as conservation agriculture, integrated nutrient management, precision agriculture, agroforestry systems, etc. Restoration of degraded soil and desertified ecosystems and the creation of positive soil and ecosystem $\mathrm{C}$ budgets are important. Urban agriculture and green roofs can reduce the energy footprint of production chains for urban and non-urban areas and enhance the recycling of by-products. Researchable priorities include sustainable land use and soil/water management options, judicious soil governance and modus operandi towards payments to land managers for the provisioning of ecosystem services.
\end{abstract}

Keywords: soil quality; food security; greenhouse effect; conservation agriculture; precision farming; integrated nutrient management; soil degradation; drought 


\section{Introduction}

The rise in global food prices [1,2] has raised concerns about food security [3] and how to feed the hungry world [4-6]. The year 2012 was marked by extreme weather in the USA [7] and globally [8], confirming the impacts of climate change on food security $[9,10]$. The world population of 7.2 billion and the atmospheric $\mathrm{CO}_{2}$ concentration of $400 \mathrm{ppmv}$ in 2013 are increasing at the annual rate of 75 million people and $2.2 \mathrm{ppmv}$, respectively [11]. Indeed, there exists a strong correlation between the human population and $\mathrm{CO}_{2}$ emission: growth in world population by one billion increases $\mathrm{CO}_{2}-\mathrm{C}$ emission from fossil fuel consumption by $1.4 \mathrm{Pg}\left(1 \mathrm{Pg}=10^{15}, \mathrm{~g}=1 \mathrm{Gt}\right)[12,13]$. That being the case, the projected increase in the world population to 9.6 billion by 2050 and 11 billion by 2100 [14] will increase $\mathrm{CO}_{2}-\mathrm{C}$ emission from $10 \mathrm{Pg}$ C/year in 2012 to $13.4 \mathrm{Pg}$ C/year by 2050 and $15.3 \mathrm{PgC} /$ year by 2100. In comparison, the Energy Information Authority [15] estimated the world's energy-related $\mathrm{CO}_{2}-\mathrm{C}$ emissions at 8.5 Pg in 2010, 9.9 Pg in 2020, 11.3 Pg in 2030 and $12.4 \mathrm{Pg}$ in 2040, with an average annual rate of increase of $1.3 \%$ per year. The EIA estimates, however, constitute only emissions from fossil fuel combustion. Further, these extrapolations of $\mathrm{CO}_{2}-\mathrm{C}$ emissions are under-estimates, because the impact (I) depends not only on the total population (P), but also on affluence (A) and technology (T) (I = PAT) [16]. The ramifications of the growing competition for soil, water and energy [17] are exacerbated by anthropogenic forces. Important among these are climate change and its uncertainties, soil resource degradation, water quality and renewability, activity and species diversity of soil flora and fauna, use efficiency of energy-based inputs, the stability and sustainability of agricultural productivity and global food security. The imbalance in food-soil-people stands out in several regions, including Sub-Saharan Africa (SSA) [18,19] and South Asia (SA) [20]. The strong nexus between fossil fuel combustion, climate change, soil degradation and food security is widely recognized [13]. Yet, there are numerous uncertainties regarding the impacts of climate [21,22] and variability on agriculture and food security [23], because of the confounding interaction with the $\mathrm{CO}_{2}$ fertilization effect as moderated by water and nutrient availability and growing risks of extreme weather [8]. China's success in feeding $20 \%$ of the world population with $7 \%$ of the arable land and $5 \%$ of the renewable water [23] has been attained at a large price tag of environmental degradation and ground water depletion. Yet, China's cereal production must be increased to $600 \mathrm{Mt}$ (million $\mathrm{Mg}$ or $\mathrm{Tg}$ ) by 2030 [24] and more so in the future. Thus, there are serious concerns about the prospects of improving crop productivity in China and globally.

Furthermore, the impact of climate change on agricultural productivity and food supply are strongly controlled by the climate-induced soil degradation, drought and heat stress at the flowering stage. Unprecedented seasonal heat can exacerbate future food insecurity [24]. An answer to the question of whether the climate change will help or hinder humanity's efforts to provide an adequate food supply depends on the type and magnitude of the attendant changes in the quality of soil and other natural resources along with drought/heat stress and on the response by adaptation through management. Furthermore, world soils can also be a source or sink of greenhouse gases (GHGs). Towards an attempt to limit global warming to $<2{ }^{\circ} \mathrm{C}$, the importance of world soils as a source or sink of GHGs has attracted the attention of land managers and policy makers to critically review an option of sequestering $\mathrm{C}$ in soils for adapting to and mitigating the anthropogenic greenhouse effect. 
The population increase by an additional 2.4 billion people by 2050 and 3.8 billion by 2100 will necessitate extra food production, for both an increase in population and, also, for growing preferences towards an animal-based diet. Wild [25] estimated that the global average cereal yield must be increased from 3.27 Mg/ha in 2005 to $3.60 \mathrm{Mg} / \mathrm{ha}$ by 2025 and $4.30 \mathrm{Mg} / \mathrm{ha}$ by 2050 without a change in dietary preferences compared with $4.40 \mathrm{Mg} / \mathrm{ha}$ by 2025 and $6.0 \mathrm{Mg} / \mathrm{ha}$ by 2050 with a change in dietary preferences (Table 1). These estimates of yield increase, however, do not consider the potential ramifications of climate change. Thus, both production (supply) and the demand for food must be addressed. The production of food depends on the quality and management of soil resources and technological interventions. Therefore, the objective of this article is to discuss the importance and technological options of sustainable soil management under changing and variable climate rising to produce enough to meet food demand.

Table 1. Required cereal yield and total production to meet future food demand (adapted from [25]).

\begin{tabular}{ccccc}
\hline \multirow{2}{*}{ Year } & \multicolumn{2}{c}{ Cereal Yield (Mg/ha) } & Total Cereal Production $\left(\mathbf{1 0}^{\mathbf{6}} \mathbf{M g} /\right.$ year $)$ \\
\cline { 2 - 5 } & Without & With & Without & With \\
\hline 2005 & 3.27 & NA & 2,240 & NA \\
2025 & 3.60 & 4.40 & 2,780 & 3,629 \\
2050 & 4.30 & 6.00 & 3,250 & 4,553 \\
\hline
\end{tabular}

Notes: Without any change to the animal-based diet; with a change to the animal-based diet; NA = data not available.

\section{Soil Resources and Sustainable Management}

Soils are essential to sustaining global food production [26], and there is as yet no viable substitute. Thus, food security solutions must be linked to the protection of natural resources, especially in developing countries [27], because these countries depend more on soil for sustaining food production than developed countries. Global soil resources are finite, unequally distributed among biomes and geographical regions, affected by climate change and variability and vulnerable to degradation (e.g., physical, chemical, biological) by land misuse and soil mismanagement; and, yet, restorable through conversion to judicious land use and appropriate management. Strongly interacting with soil, in the context of agronomic production in a changing and variable climate, is the supply and quality of water. Soils must be framed as a key actor when dealing with complex environmental problems [28]. Thus, pertinent issues with regards to soil and water resources are as follows [29]:

(i) Actual and potentially available soil resources;

(ii) Loss of soil resources to climate-induced degradation;

(iii) Degradation of soil by land use and soil mismanagement;

(iv) Determinants of soil resilience to abiotic and biotic stresses;

(v) Strategies of soil restoration in the context of threshold levels of key soil properties and their dynamics;

(vi) Global and regional hot spots of soil degradation; and

(vii) Sustainable intensification of soils devoted to agroecosystems. 
These issues, important as these are, even by themselves, become especially critical in the context of achieving food security in the face of climate change [30]. The data in Table 2 show a severe yield reduction of the staple food crops (maize, rice, wheat) in SSA, SA and elsewhere among developing countries [31-33], probably because of soil and environmental degradation. The possible positive response to total global cereal production because of the so-called " $\mathrm{CO}_{2}$ fertilization effect" (Table 3) strongly depends on the adequate supply of plant nutrients (N, P, K, S) and water [34]. The supply of plant nutrients and water, however, is mediated though the quality of soil resources and supplemented by fertilizer and irrigation.

Table 2. Reduction (\%) in crop yields by 2050 in global hotpots of climate change (adapted from [31,33]).

\begin{tabular}{lcccccc}
\hline \multirow{2}{*}{ Region } & \multicolumn{3}{c}{ Un Irrigated } & \multicolumn{3}{c}{ Irrigated } \\
\cline { 2 - 7 } & Maize & Rice & Wheat & Maize & Rice & Wheat \\
\hline Sub-Saharan Africa & 14.6 & 11.5 & 32.8 & 39.7 & 39.4 & 34.5 \\
South Asia & 36.8 & 16.4 & 54.7 & 26.0 & 19.8 & 50.1 \\
Latin America and the Caribbean & 11.2 & 20.7 & 4.9 & 23.9 & 24.9 & 21.5 \\
Developed Countries & 6.0 & 30.5 & 17.1 & 3.2 & 17.3 & 22.6 \\
Developing Countries & 15.6 & 13.1 & 31.0 & 15.7 & 22.6 & 37.5 \\
World & 12.7 & 13.1 & 24.5 & 8.9 & 22.3 & 35.5 \\
\hline
\end{tabular}

Note: The reduction in crop yield is more from irrigation than under rainfed conditions, because the relative yield is higher in the former than in later ecoregions.

Table 3. Estimates of $\mathrm{CO}_{2}$ fertilization effect on average annual global cereal production $\left(10^{6} \mathrm{Mg}\right)$ with and without the projected climate change (adapted from [31,33]).

\begin{tabular}{ccccc}
\hline \multirow{2}{*}{ Decade } & \multicolumn{4}{c}{ Stabilization of Atmospheric $\mathbf{C O}_{\mathbf{2}}$} \\
\cline { 2 - 5 } & No Climate Change & Unmitigated & $\mathbf{5 5 0} \mathbf{~ p p m v}$ & $\mathbf{7 5 0} \mathbf{~ p p m v}$ \\
\hline 1990 & 1,800 & & & \\
2020 & 2,700 & 2,670 & 2,676 & 2,672 \\
2050 & 3,500 & 3,475 & 3,477 & 3,473 \\
2080 & 4,000 & 3,927 & 3,949 & 3,987 \\
\hline
\end{tabular}

Despite the unique success in advancing agricultural production since 1980, even China's food security is threatened by soil degradation [35]. It is estimated that the relationship between food supply and demand may be changed from an $18 \%$ surplus in 2005 to $20 \%-30 \%$ deficit by $2030-2050$ because of soil degradation. Even the low-carbon innovations may jeopardize and disrupt the food supply in China [36]. Resource use efficiency must be increased to improve food security and improve environmental quality in China [37]. Soil degradation decreases productivity through low resource use efficiency, especially that of $\mathrm{N} \mathrm{[38]} \mathrm{and} \mathrm{water} \mathrm{[39].} \mathrm{While} \mathrm{some} \mathrm{countries} \mathrm{can} \mathrm{reduce} \mathrm{the} \mathrm{dependence}$ on synthetic fertilizers by growing legumes, even biological nitrogen fixation (BNF) has ecological tradeoffs, because of some negative environmental impacts [40].

The potentially available soil resources that may presumably exist in SSA and South America [41,42] are located in ecologically sensitive ecoregions. Thus, the strategy is to grow more from less through sustainable intensification and turn the so-called "dust bowl" into a 
"cereal bowl" through soil restoration. Long-term soil and water conservation measures are needed in vulnerable regions, like Ethiopia and other East African Highlands [43].

Whereas soil degradation is widely recognized and an integrated effort to achieve zero net land degradation was proposed at the U.N. meeting organized in Rio de Janeiro, Brazil in 2012, there are few if any hard data obtained though systematic assessment on the type, extent and severity of soil degradation. Most of the available statistics are based on qualitative expert judgments [44,45] or remotely sensed quantitative proxy values [46]. Oldeman [45] reported global assessment of soil degradation by different processes on the continental scale (Table 4). The data show that by 1990, as much as 1.96 billion hectares (Bha) of soil had been degraded to some degree, and accelerated erosion by water and wind were presumably the most widespread problems. A similar attempt had been made by UNEP/FAO to estimate the land area affected by desertification [44].

Table 4. Estimates of anthropogenic soil degradation (recalculated from [45]).

\begin{tabular}{lcccccc}
\hline & \multicolumn{5}{c}{ Area Affected (106 ha) } \\
\cline { 2 - 6 } Type & Africa & Asia & $\begin{array}{c}\text { Australia } \\
\text { and Pacific }\end{array}$ & Europe & $\begin{array}{c}\text { Latin America } \\
\text { and Caribbean }\end{array}$ & World Total \\
\hline Water Erosion & 227 & 440 & 83 & 115 & 169 & 1,094 \\
Wind Erosion & 187 & 222 & 16 & 42 & 47 & 548 \\
Nutrient Depletion & 45 & 15 & - & 3 & 72 & 135 \\
Salinization & 15 & 53 & 1 & 4 & 4 & 76 \\
Contamination & - & 2 & - & 19 & - & 22 \\
Physical Degradation & 4 & 12 & 2 & 36 & 13 & 79 \\
Others & 1 & 3 & 1 & 2 & 1 & 10 \\
Total & 287 & 747 & 103 & 218 & 306 & 1,964 \\
\hline
\end{tabular}

Proxy global assessments of land degradation, using remotely sensed normalized difference vegetation index (NDVI) data, have been made by Bai et al. [46]. The data in Table 5 indicate that $24 \%$ of the global land area is affected by degradation. Global hot spots of land degradation include SSA, with specific reference to ecoregions south of the Equator, South-East Asia and South China, north-central Australia, the Pampas and parts of the Siberian and North American Taiga. These regions prone to degradation affect 1.5 billion people.

Similar to the problem of a credible assessment of the extent and severity of soil degradation, there are few reliable estimates assessing the impact of soil degradation on agronomic production [19]. Data on the cause-effect relationship between specific degradation processes and agronomic yield are few. Some examples of empirical relationships include the following:

(i) Soil organic C concentration vs. crop yield [47,48];

(ii) Soil erosion vs. crop yield [49-51];

(iii) Soil salinity $v s$. crop yield [52];

(iv) Nutrient depletion [53];

(v) Soil compaction vs. crop yield [54]. 
Table 5. Global estimates of land degradation between 1981 and 2003 (recalculated from [45]).

\begin{tabular}{lccc}
\hline Region & \# of Countries & Degrading Area $\left(\mathbf{1 0}^{\mathbf{6}} \mathbf{~ k m}^{\mathbf{2}}\right)$ & Affected People in 2008 (10 $\mathbf{6}$ \\
\hline Sub-Saharan Africa & 44 & 6.4 & 196 \\
Central Asia & 6 & 0.5 & 4 \\
South Asia & 8 & 0.8 & 274 \\
East Asia & 5 & 2.4 & 512 \\
Southeast Asia & 10 & 2.4 & 228 \\
The Caribbean & 8 & 0.3 & 12 \\
Central America & 8 & 1.1 & 45 \\
Latin America & 10 & 0.6 & 128 \\
World & 10 & 35.1 & 1,538 \\
\hline
\end{tabular}

Note: Mexico is included in both Latin America and Central America.

Nkonya et al. [55] documented that cost of no-action to alleviate the problem of soil degradation exceeds that of a judicious action to prevent it or manage it. The per capita arable land areas and water resources are rapidly declining with the increase in population and conversion to other uses (Table 6). Furthermore, the productivity of these lands is being severely jeopardized by accelerated erosion. There exists a large yield gap between the actual and attainable crop yields (Table 7), because of erosion, nutrient depletion and other degradation processes.

Table 6. Temporal changes in per capita land area for some regions (recalculated from [55]).

\begin{tabular}{lccc}
\hline \multicolumn{4}{c}{ Per Capita Land Area (ha/person) } \\
Region & $\mathbf{1 9 7 0}$ & $\mathbf{2 0 0 4}$ & Rate of Decline (ha/person/yr) \\
\hline Sub-Saharan Africa & 0.48 & 0.38 & 0.007 \\
Latin America & 0.39 & 0.27 & 0.004 \\
South Asia & 0.27 & 0.13 & 0.004 \\
East Asia & 0.13 & 0.11 & 0.001 \\
\hline
\end{tabular}

Table 7. Yield gap (experimental — national average) in major food crops in countries within high global hot spots of climate change (adapted from [56]).

\begin{tabular}{|c|c|c|c|c|c|c|c|c|}
\hline \multicolumn{3}{|c|}{ Maize (Mg/ha) } & \multicolumn{3}{|c|}{ Rice (Mg/ha) } & \multicolumn{3}{|c|}{ Wheat $*(\mathrm{Mg} / \mathrm{ha})$} \\
\hline $\begin{array}{l}\text { Country/ } \\
\text { Region }\end{array}$ & Average & Potential & $\begin{array}{l}\text { Country/ } \\
\text { Region }\end{array}$ & Average & Potential & $\begin{array}{l}\text { Country/ } \\
\text { Region }\end{array}$ & Average & Potential \\
\hline SSA: & & & China: & 5.9 & 7.6 & Northern India & 3.0 & 7.5 \\
\hline Sub-Tropical/Mid Latin & 2.5 & 7.0 & Early Crop & 5.6 & 9.8 & Punjab & 4.1 & 5.5 \\
\hline Tropical Lowland & 0.7 & 4.5 & Late Crop & 5.6 & 9.5 & Haryana & 3.8 & 4.0 \\
\hline West Kenya & 1.7 & 3.7 & Single Crop & 7.2 & 11.5 & Bihar & 2.8 & 3.8 \\
\hline Tropical Lowland & 1.4 & 4.5 & India: & 3.6 & 5.9 & Bangladesh ** & 2.9 & 4.2 \\
\hline
\end{tabular}


Table 7. Cont.

\begin{tabular}{|c|c|c|c|c|c|c|c|c|}
\hline \multicolumn{3}{|c|}{ Maize (Mg/ha) } & \multicolumn{3}{|c|}{ Rice (Mg/ha) } & \multicolumn{3}{|c|}{ Wheat * $(\mathrm{Mg} / \mathrm{ha})$} \\
\hline $\begin{array}{l}\text { Country/ } \\
\text { Region }\end{array}$ & Average & Potential & $\begin{array}{l}\text { Country/ } \\
\text { Region }\end{array}$ & Average & Potential & $\begin{array}{l}\text { Country/ } \\
\text { Region }\end{array}$ & Average & Potential \\
\hline SEA, EA: & & & Punjab & 5.0 & 6.5 & Mexico ** & & \\
\hline Tropical Lowland & 2.2 & 5.5 & W. Bengal & 3.1 & 5.0 & Yaqui Valley & 5.8 & 8.2 \\
\hline Sub-Trop./Mid Lat. & 3.0 & 8.0 & Bihar & 1.8 & 6.1 & San Lui Rio, CO & 6.4 & 9.0 \\
\hline LA: & & & Orissa & 2.0 & 5.6 & & & \\
\hline Highlands & 4.0 & 10.0 & U.P. & 2.9 & 6.6 & & & \\
\hline Tropical Lowlands & 1.5 & 5.0 & & & & & & \\
\hline USA (Nebraska): & & & & & & & & \\
\hline Model & 10 & 18 & & & & & & \\
\hline Rainfed & 6 & 15 & & & & & & \\
\hline
\end{tabular}

Notes: SSA, Sub-Saharan Africa; * Modeled yield; ** maximum farmer yield; LA, Latin America; SEA, South East Asia; EA, East Asia; U.P., Uttar Pradesh.

\section{Vulnerability to Climate Change}

Anthropogenic activities have drastically transformed the biosphere. Humans appropriate about $40 \%$ of terrestrial photosynthesis and are the cause of the $50 \%$ of the global $\mathrm{N}$ flux from synthetic fertilizers and fossil fuel combustion and $>50 \%$ of the renewable fresh water withdrawal [57]. Therefore, the continuing increase in population and consumption growth until the year 2100 [58] imply even more exploitation of the planet. Thus, there is an urgency to reduce the impact of agroecosystems on the environment [59]. The record-breaking weather events of 2011 and 2012, along with the severity of wildfires and tornados, in conjunction with alternating droughts and floods, are indicative of anthropogenic climate changes. The severe drought experienced during the summer of 2012 in the U.S. Midwest pales in comparison with the large drought and heat wave experienced in Texas during 2011 and 2012 [60,61]. Thus, any strategy to achieve food production sustainability must also address climate change. It is feared that more than 100 million people may perish as a result of climate change by 2030 [62]. Hatfield et al. [63] observed that in the U.S., there is a variation among crops in their response to $\mathrm{CO}_{2}$, temperature and precipitation changes, along with regional differences in predicted climate. Climate change may influence food production directly (Figure 1) by affecting crop growth (e.g., drought, floods, length of growing season, suboptimal or supra-optimal temperatures) or indirectly by altering the ground water and the incidence of pests and pathogens $[24,64,65]$. Over and above that, there are issues of the declining rates of growth of crop yields, especially in parts of SSA, SA and Central and South America. Global per capita cereal production may decline by $14 \%$ between 2008 and 2030 [66]. The region at the greatest risk of food insecurity is SSA [9], where a third of the total population already faces hunger and malnutrition [67]. The climate in SSA is already experiencing significant changes, especially in the drought-sensitive savanna zones of Ghana [68] and elsewhere in the Sahel. Thus, the area suitable for agriculture, the length of the growing seasons and yield potentials are expected to decrease, especially along the margins of semi-arid and arid areas [69]. There are serious questions regarding the survivability of agriculture in SSA [70], at least that of the subsistence low/no-input farming practiced by the smallholder. Most modeling 
studies indicate a negative impact of climate change on food crops in SSA [71]. Regions in SSA that are likely to remain hot spots of food insecurity include those in Ethiopia, Uganda, Rwanda and Burundi, southwestern Niger and Madagascar [72]. In Ghana, West Africa, the Guinea savanna agroecological zone has experienced delayed rains between 1960 and 2008 in comparison with slightly earlier rains over the same periods for the Sudan savanna zone. Food production risks at the household level depend on the occurrence of extreme events. Thus, the mean yield may be an inaccurate risk predictor [73].

Figure 1. Direct and indirect effects of human-induced climate change on food security, which can be negative or positive, depending on the biome and regional characteristics.

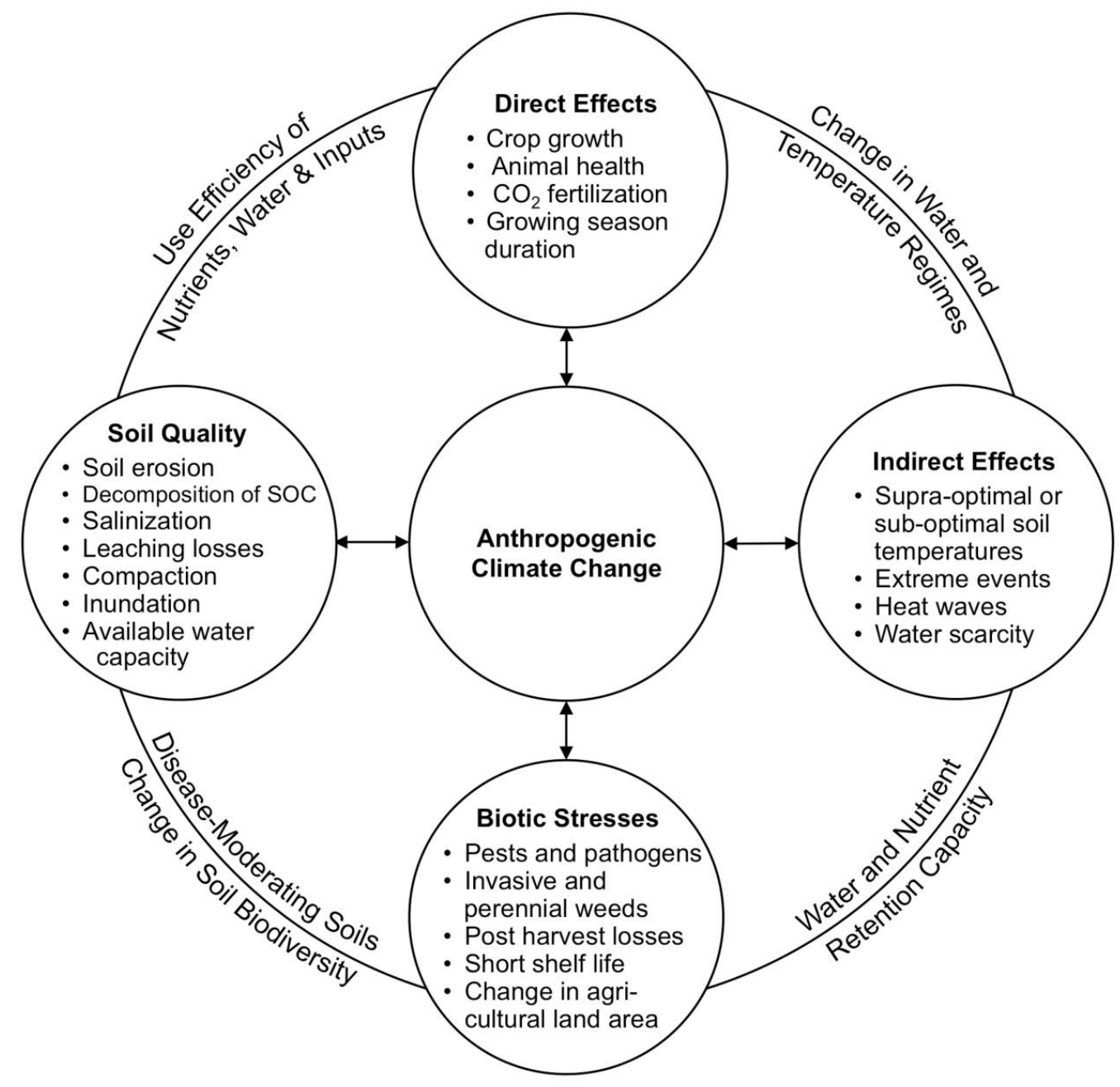

Note: SOC, soil organic carbon.

With $20 \%$ of the world population, a limited arable land area and scarce renewable fresh water, China is another region vulnerable to declining food production under changing and variable climate [74]. It is estimated that crops may experience a $9 \%$ loss in productivity by 2030 and $30 \%$ by 2050 , with risks of severe soil degradation [75]. It is concluded that production may decrease from $18 \%$ surplus in 2005 to $22 \%-32 \%$ deficits by 2030-2050, with a doubling of the rate of soil degradation [75]. Environmental degradation is also affecting the air quality in Beijing. Judicious governance is an important consideration [76]. 
Increasing atmospheric concentration of GHGs and the attendant climatic changes could greatly aggravate the risks of drought (e.g., the 2012 drought in the USA. Corn Belt), flooding (2010 in Australia and Pakistan), wild fires (2012 and 2013 in the western USA) and the incidence of pests (locust in Sahel) and pathogens. These events may get even worse and aggravate the vulnerability of the agroecosystems to harsh climate. Smallholders are likely to be more vulnerable than large-scale commercial farmers [77-79]. Food security is influenced by the direct and indirect effects of climate change (Figure 1) and through short-term and long-term changes in soil quality (Figure 2). It is important to realize, however, that the effects of climate change may be both positive and negative. There will be opportunities for improving agricultural production, which must be fully explored.

Figure 2. The effects of climate change on alterations (negative or positive) in soil properties and processes.

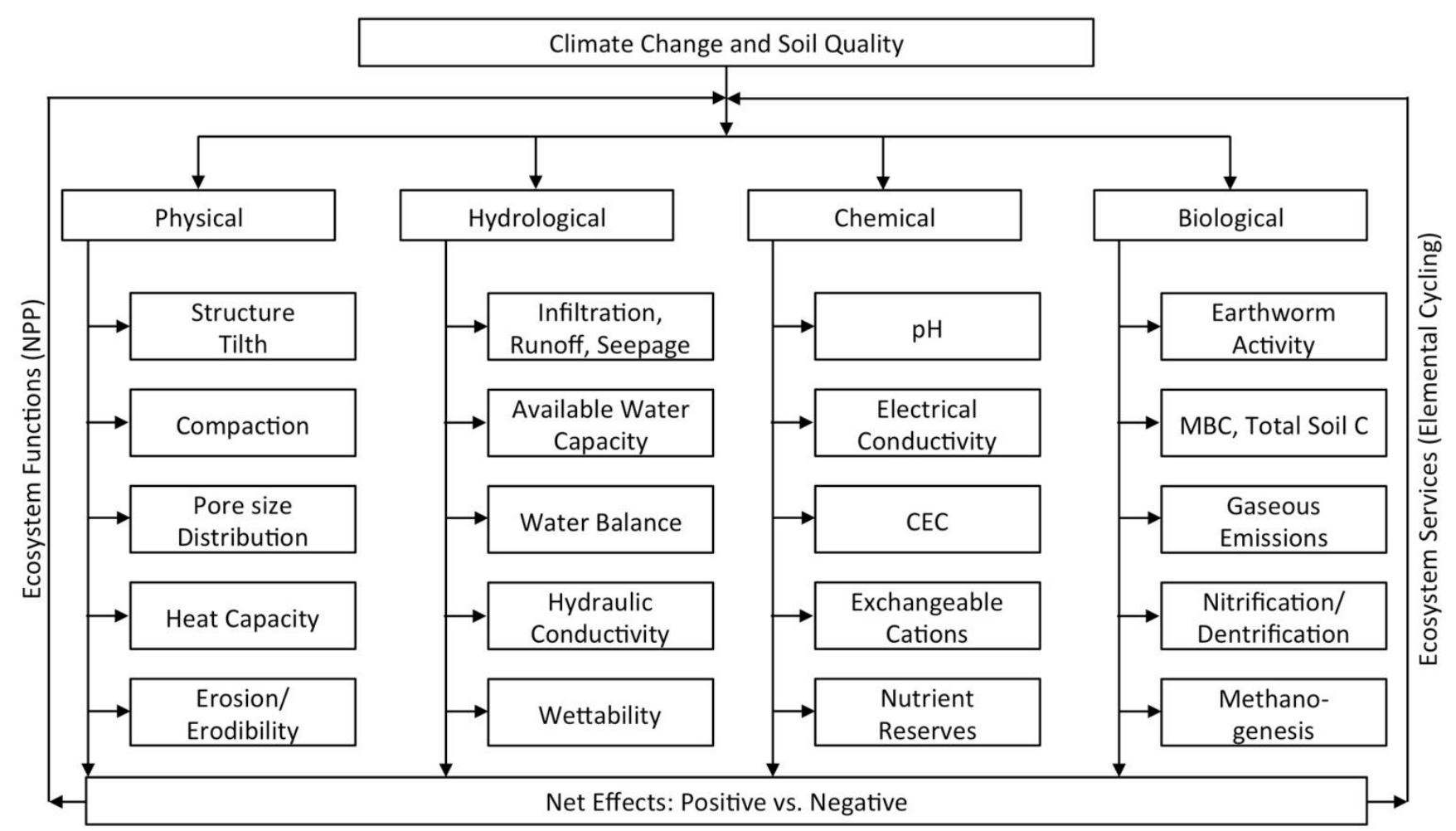

Notes: CEC, cation exchange capacity; MBC, microbial biomass C; NPP, net primary productivity.

\section{Yield Gap}

Agronomic productivity of several agroecosystems (dryland farming with low input and extractive practices), such as the semi-arid tropics [80], is much lower than their potential agricultural production. The yield gap, the difference between actual and potential yields (Tables 7 and 8), may be increasing because of the high climatic variability and extreme events [81]. The yield gap is smaller in irrigated compared with rainfed/dryland systems [56]. A principal factor of a large yield gap in rainfed ecosystems in semi-arid climates is attributed to the uncertainty in the growing season weather. Yet, the yield gap also exists in irrigated rice $[82,83]$, which may be due to management factors. The yield gap, because of soil quality and climatic factors, can exist in any crop, including biofuel 
plantations. Therefore, nutrient and water management are critical to closing the yield gaps, especially in SSA, SA and elsewhere in developing countries.

Table 8. Actual and potential yields of different crops of the semi-arid tropics (SAT) climates (adapted from [80]).

\begin{tabular}{|c|c|c|c|c|}
\hline \multirow{2}{*}{ Region } & \multirow{2}{*}{ Crop } & \multicolumn{2}{|c|}{ Yield (kg/ha) } & \multirow{2}{*}{ Ratio (Potential:Actual) } \\
\hline & & Actual & Potential & \\
\hline SAT-1 & Maize & 1,460 & 3,410 & 2.3 \\
\hline SAT-2 & Maize & 1,460 & 7,330 & 5.0 \\
\hline SAT-1 & Groundnut & 980 & 2,400 & 2.5 \\
\hline SAT-2 & Groundnut & 980 & 4,080 & 4.2 \\
\hline SAT-1 & Pearl Millet & 690 & 2,660 & 3.9 \\
\hline SAT-2 & Pearl Millet & 690 & 2,950 & 4.3 \\
\hline SAT-1 & Sorghum & 1,170 & 4,030 & 3.5 \\
\hline SAT-2 & Sorghum & 1,170 & 5,910 & 5.1 \\
\hline SAT-1 & Soybean & 1,420 & 2,590 & 1.8 \\
\hline SAT-2 & Soybean & 1,420 & 4,760 & 3.3 \\
\hline
\end{tabular}

Notes: SAT-1 $=$ growing period of $75-120$ days; SAT-2 = growing period of 120-180 days.

\section{Adaptation to Climate Change}

The revised population estimates [14] of 9.6 billion people by 2050 and 11 billion by 2100 have aggravated the Malthusian alarmism in: how these extra 2.4 billion mouths by 2050 are to be fed? Appropriate measures (general vs. specific, reactive vs. anticipatory, autonomous vs. planned, scientific $v s$. traditional knowledge, economic $v s$. ecologic, etc.) are needed as adaptive strategies to reduce the vulnerability of agroecosystems to climate change. Farmers, even those of SSA and SA, have demonstrated a strong adaptability in the past to numerous challenges [71], and they will rise to the occasion to meet any future challenges, as well. Whereas the role of agronomic research in climate change [84] for rice-based systems in SSA [85] along with economic and policy perspective [86] can never be overemphasized, promoting the adoption of proven technologies is essential over the short-time horizon (decadal scale). There exists a wide spectrum of site-specific technologies (e.g., crop rotation, time of sowing, manuring, crop diversification, residue management, integrated pest management) to manage the risks and to reduce vulnerability. In addition, some long-term adaptive options include irrigation, salinity reclamation, land forming, runoff management, etc. The strategy is to enhance the resilience of agroecosystems.

The yield gap must be bridged through the choice and implementation of adaptive measures because of increasing demands for food. Tilman et al. [87,88] estimated a 100\%-110\% increase in global crop demand from 2005 to 2050 . Further, the environmental impact of meeting the demand depends on technological strategies. Further, investments needed for adaptation must favor specific crops (rice, wheat, maize, root crops) and regions (SSA, SA) [89]. Sustainable intensification can produce more from the same (existing) area of land, while reducing the environmental impact by enhancing the efficiency of both inherent resources and off-farm input [3]. There is a wide range of options available to reduce some negative externalities. For example, supplemental irrigation has been 
a major tool of intensification and improving productivity in SA. Yet, it has also aggravated the risks of secondary salinization and exacerbated environmental degradation [90]. Tilman et al. [87,88] showed that the adoption of efficient management practices could substantially lower $\mathrm{N}$ use and also decrease the need for bringing additional deforestation. Sustainable intensification, producing more from less, can also mitigate the emissions of GHGs and also has strong mitigation potential [91]. Burney et al. [92] observed that while emissions of GHGs increased from the use of fertilizers, the net effect of higher yields decreased the emissions by $161 \mathrm{Pg} \mathrm{C}\left(590 \mathrm{Pg} \mathrm{CO}_{2}\right.$ e) between 1961 and 2005. Each dollar invested in agricultural yield reduced emissions by $68 \mathrm{Kg} \mathrm{C}\left(249 \mathrm{Pg} \mathrm{CO}_{2} \mathrm{e}\right)$ relative to the 1961 baseline technology, thereby avoiding 3.6 Pg C emissions per year [92]. Thus, investments in yield improvement compare favorably with other mitigation strategies. Therefore, tremendous progress could be made by halting agricultural expansion, closing the yield gap on underperforming lands, identifying possible causes of yield failure (such as low yields in tropical aerobic rice) [93,94], increasing the use efficiency of inputs along with reducing waste and shifting diets [95]. A multifaceted and linked global strategy is needed to ensure sustainable and equitable food security [3]. It has been argued that food production can be tripled in SSA by adopting proven technologies of agricultural intensification [96], including the cultivation of perennial grains [97], active selection and breeding of $\mathrm{CO}_{2}$ responsiveness among cereal varieties [98] and the sustainable management of grasslands [99]. Domestic livestock can play a major role in mitigating climate change [100]; judicious management of grazing lands has a large potential for soil C sequestration [101].

\section{Technological Options}

The Malthusian alarmism has thus far been proven wrong by technological progress (Figure 3: 1960-2000). The Green Revolution package of the 1960s input responsive varieties grown under irrigated conditions with liberal doses of fertilizers and chemicals, saved hundreds of millions from starvation in SA, Southeast Asia, Central America and elsewhere. However, the Green Revolution bypassed SSA, where, with a few exceptions, agronomic yields have thus far stagnated at the level of the 1960s. Therefore, the question about the strategic research needs towards agricultural intensification between 2010 and 2050 and between 2050 and 2100 must be critically and objectively addressed (Figure 3: 2000-2100). Lal and Stewart [102] emphasized the importance of soil-based technology. Lal [103] reiterated that the potential of the improved varieties can be realized only when grown under optimal edaphological conditions, because even the elite varieties cannot extract water and nutrients from depleted soils where they do not exist. Critical soil-based issues that need to be addressed are discussed below. 
Figure 3. Technological evolution and future innovative and emerging technologies (updated from [104])

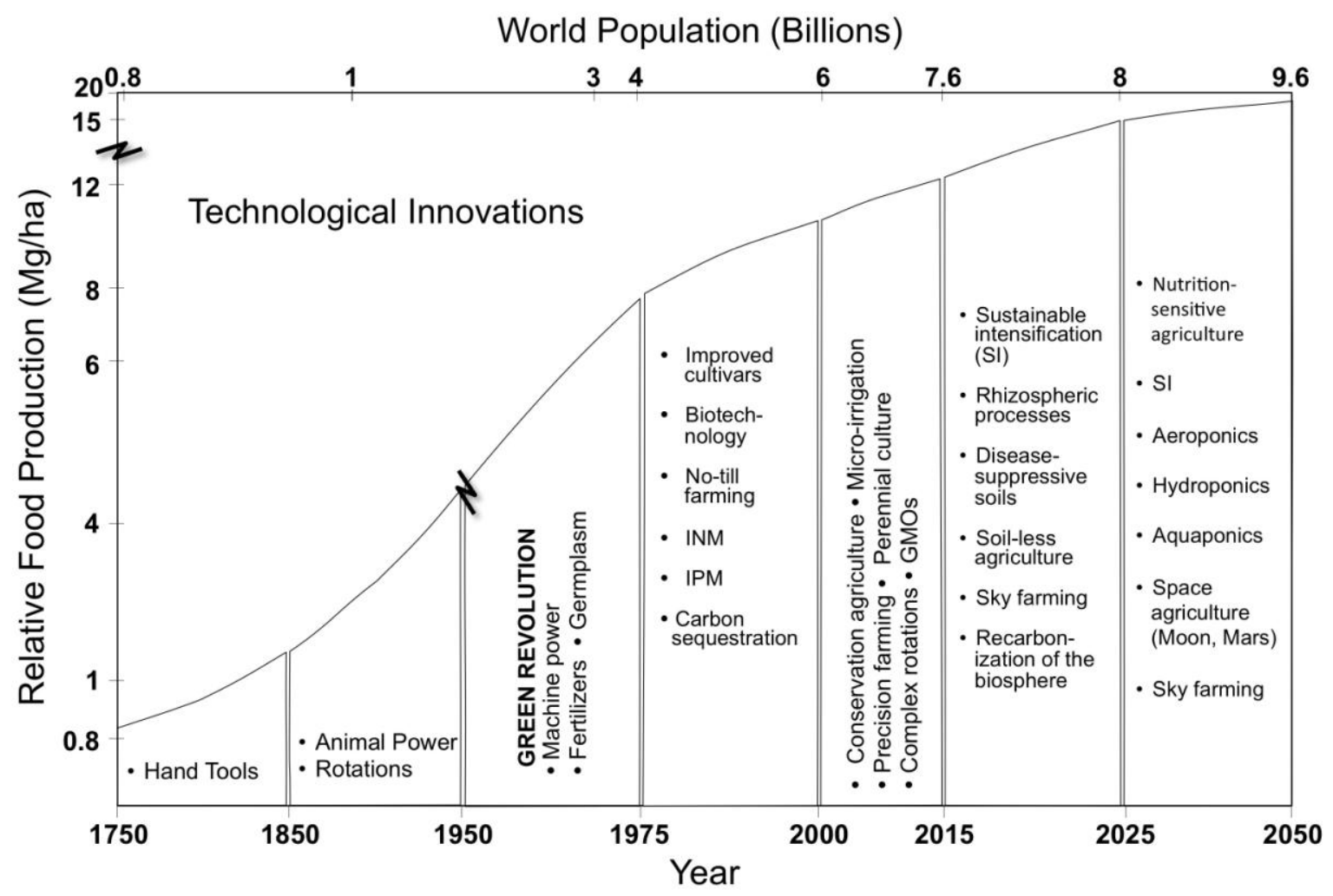

Notes: INM, integrated nutrient management; IPM, integrated pest management; SI, sustainable intensification.

\section{Managing Water for Alleviating Drought Stress}

Enhancing the "green water" supply in the root zone is essential to the sustainability of agriculture in arid, semi-arid and sub-humid regions. The strategy is to improve yield per unit of rainfall in dryland agriculture (more crop per drop). It is argued that supplemental irrigation, based on water harvesting and application through micro-irrigation technologies (e.g., drip sub-irrigation), is a practical adaptation to climate change and variability in SSA [70] and the ground water-based irrigation in SA [105]. Nonetheless, the effectiveness of irrigation and sustainable use of limited water resources involves improving intrinsic water-use efficiency (WUE) and crop yield. The latter is defined as the ratio of the instantaneous rates of $\mathrm{CO}_{2}$ assimilation (A) and transpiration (T) at the stomata [106]. While understanding plant physiological attributes are critical, including the possible gains by the $\mathrm{CO}_{2}$ fertilization effects, soil quality and its management to enhance plant-available water capacity are also essential. The problem of low WUE is strongly confounded by soil degradation [107]. Thus, restoration of soil quality to improve green water is a prudent strategy. In addition to having lower opportunity cost, the use of green water to increase agronomic production has lesser environmental externalities compared with the use of blue water involving irrigation through canal or ground water [108]. The externalities of blue water use can be minimized through the uptake of precision irrigation techniques. Precision irrigation is defined as "site-specific irrigation management that relies on variable application of water". It is emerging as a potential solution to increase the productivity and reduce the environmental impact of irrigated agriculture [30,109]. The strategy is to match irrigation to 
soil type, the inherent permeability and water/nutrient retention capacity by using irrigation techniques in conjunction with a variable rate of water applications. Micro-irrigation (drip or trickle) is a water saving, but an expensive, option. In comparison, precision irrigation through the sub-division of control zones and electronic controllers may be efficient and economical. Precision irrigation can be used in conjunction with the concept of regulated deficit irrigation (RDI) or partial root zone drying (PRD) [110]. Subjected to drought stress, roots generate abscisic acid (ABA), which moderates stomatal closure [111]. Withholding irrigation also stimulates deeper rooting, reduces irrigation needs, and enhances resilience. Three challenges of using micro-irrigation are [110]: (i) monitoring variable/heterogeneous soil moisture content by using electromagnetic induction and near-infrared systems mounted on unmanned aerial vehicles; (ii) measuring plant-water status and regulating irrigation through it by using high resolution and high frequency remote sensing (e.g., MODIS) technology; and (iii) applying variable rate of water irrigation. There are numerous proven options of enhancing the WUE, and their adoption must be promoted through soil governance. Improving soil fertility by establishing fertilizer trees [112] can also improve WUE in drought-prone agroecosystems.

Rainwater harvesting and management is a useful strategy to store the excess water and reuse it during the dry season. This strategy is especially relevant to rainfed agriculture in SSA, SA, etc., and is relevant to smallholder farmers to intensify production systems [113].

Rice, a semi-aquatic plant and a major food staple of the world, has a high water requirement and a large yield gap, which must be closed [83]. Flooded paddies in an arid environment, such as in western parts of the Indo-Gangetic Plains, have been responsible for the rapid depletion of the ground water. Water scarcity, exacerbated by extreme events and climate change, necessitates the identification of water-saving strategies. Therefore, aerobic rice is a viable option [114-117] for increasing WUE even with a slight decline in agronomic yield [118]. Crop yields of aerobic rice can be enhanced by $\mathrm{N}$ management [119-121]. Among several challenges that remain to be addressed in promoting aerobic rice is soil sickness caused by aerobic monocropping [122,123]. Micronutrient deficiency and effective weed control are other factors to be considered under continuous aerobic rice cultivation. With appropriate management, the grain yield of aerobic rice in the north China Plains could be up to $7 \mathrm{Mg} / \mathrm{ha}[119,120]$ compared with an aerobic yield of $8 \mathrm{Mg} / \mathrm{ha}$ or more.

Strategies for soil water management are outlined in Figure 4, and those of improving productivity on the plant scale are conceptualized in Figure 5. Identifying and implementing practical solutions under site-specific conditions require multi-disciplinary, adaptive and applied research programs. 
Figure 4. Principles and practices of enhancing the water use efficiency.

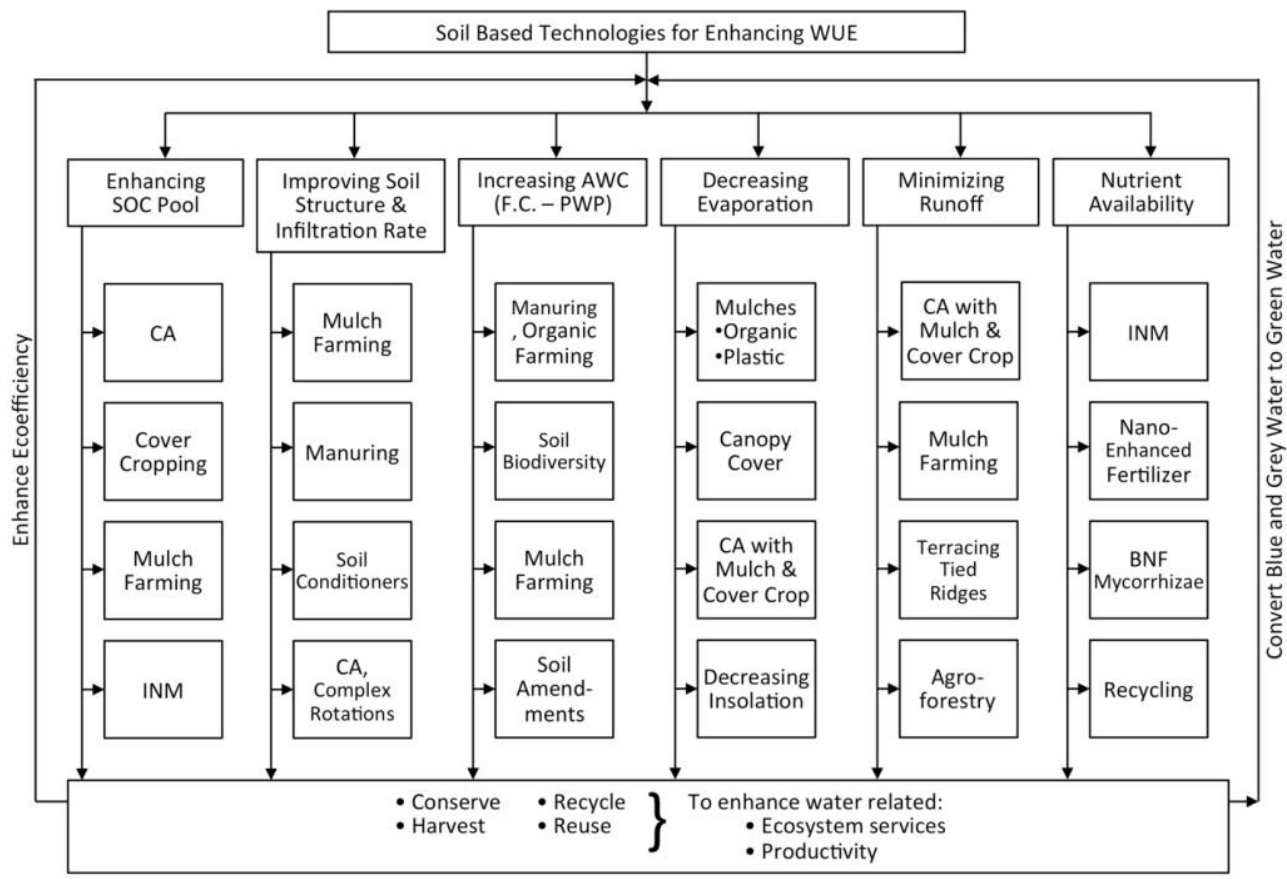

Notes: CA, conservation agriculture; INM, integrated nutrient management; BNF, biological nitrogen fixation; F.C., field moisture capacity; PWP, permanent wilting point; WUE, water-use efficiency; AWC, available water capacity.

Figure 5. Halting agricultural expansion while achieving food security, mitigating climate change through soil and water management and altering consumption patterns and food preferences.

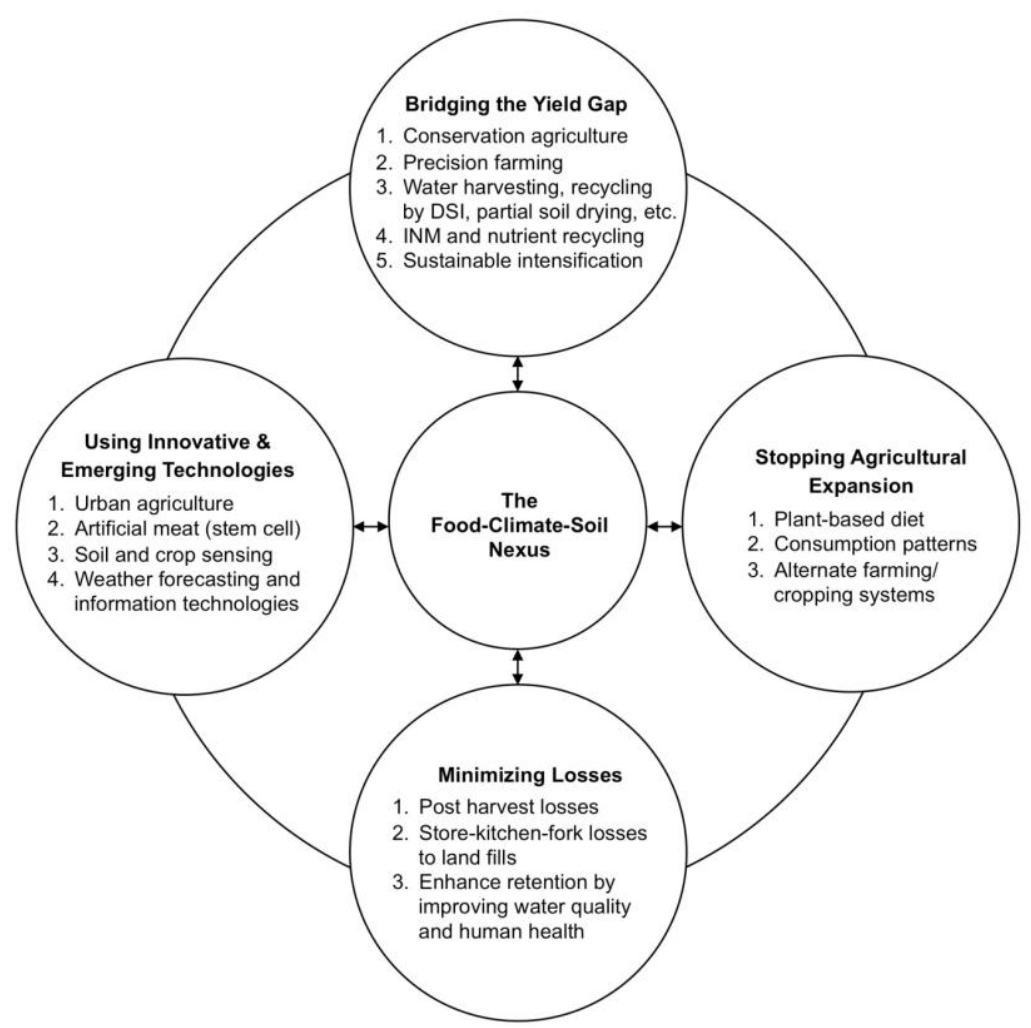

Notes: DSI, drip sub-irrigation; INM, integrated nutrient management. 


\section{Sustainable Intensification}

Simple, but innovative, methods of intensification can drastically increase the productivity of small farms, which characterize agriculture in Asia and Africa [124]. Makurira et al. [125] observed that maize yield in semi-arid Tanzania could be increased from $1 \mathrm{Mg} / \mathrm{ha}$ to $4.8 \mathrm{Mg} / \mathrm{ha}$ and water productivity up to 0.35 to $0.51 \mathrm{~kg} / \mathrm{m}^{3}$ with the adoption of simple techniques for soil and water conservation. Increased productivity and food security in SSA can be achieved through key interventions, including soil fertility improvements, water management and improvements in weather forecasting, among others [126]. Efficient management practices of sustainable intensification (producing more from less) could reduce the use of inorganic $\mathrm{N}$ and other inputs. Tilman et al. [87,88] estimated that with business as usual, about one billion hectares (Bha) of additional land would be cleared globally by 2050 with $\mathrm{CO}_{2}-\mathrm{C}$ equivalent emission of $3 \mathrm{Pg} \mathrm{C} / \mathrm{yr}$ and $\mathrm{N}$ use of $250 \mathrm{Tg} / \mathrm{year}$. In contrast, the adoption of recommended management practices (RMPs) of sustainable intensification would require only $\sim 0.2$ Bha of additional land and global $\mathrm{N}$ use of $\sim 225 \mathrm{Tg} / \mathrm{year}$. There is a strong case for a paradigm shift in land husbandry in SSA [20]. Agricultural intensification is a viable option to GHG mitigation [92], while advancing food security. Towards an attempt to address climate change and variability, there is a growing interest in restoring the ecosystem $\mathrm{C}$ pool of the terrestrial ecosystems in general and the soil organic carbon (SOC) pool in particular. Many agricultural lands, especially those in the developing countries of the tropics and sub-tropics, have been over-exploited through perpetual use of extractive farming practices. Thus, improved management of the soils of agroecosystems can restore the SOC pool. Restoration of the SOC pool involves creating a positive ecosystem $\mathrm{C}$ budget through: (i) increasing the soil application (input) of biomass-C; (ii) decreasing losses of SOC by water runoff and soil erosion by water and wind; (iii) moderating soil temperature and reducing the rates of mineralization; and (iv) enhancing the mean residence time (MRT) of SOC by increasing soil aggregation and stability and the stabilized fraction. These concepts can be realized through a range of soil/crop/water/nutrient management practices, including: (i) conservation agriculture (CA) in conjunction with mulch farming, cover cropping and complex rotations; (ii) agroforestry systems; and (iii) perennial culture, among others $[127,128]$. However, there is no panacea, and no practice is universally applicable. Indeed, even conservation agriculture/no-till (CA/NT) farming may neither enhance the SOC pool nor crop yields under all biomes and soil types $[26,129,130]$. Further, soils and climate factors impact NT yields relative to plow tillage (PT). Comparing yields from 442 paired tillage experiments across the U.S. for six crops, Toliver et al. [131] reported that in general, mean yields of sorghum and wheat with CA/NT were more than with PT. Furthermore, CA/NT performed satisfactorily on loamy soils in the Southern Seaboard and Mississippi Portal regions. In general, CA performed poorly on sandy soils. In addition to yield, the CA system also requires less fuel consumption: $28 \mathrm{~L} / \mathrm{ha}$ reduction under reduced tillage compared with $41 \mathrm{~L} / \mathrm{ha}$ under NT [132]. In some soils, permanent raised beds can be useful [133]. Increasing agronomic yield per unit area, time and input (through sustainable intensification) by the adoption of these techniques has and can spare forests and prairies from expansion into new agricultural lands. Through the increase in SOC and the ecosystem C pool, the GHG emissions by anthropogenic activities can be offset. Burney et al. [92] estimated that increasing crop yield has avoided emissions of $161 \mathrm{Pg} \mathrm{C}$ (590 Pg of $\mathrm{CO}_{2} \mathrm{e}$ ) since 1961 and that each dollar invested in agricultural yield has resulted in 68 fewer 
$\mathrm{kg} \mathrm{C}$ (249 $\mathrm{Pg}$ of $\mathrm{CO}_{2} \mathrm{e}$ ) relative to 1961 technology, avoiding $~ 3.6 \mathrm{Pg} \mathrm{C}$ per year. Case studies show that the adoption of RMPs can potentially sequester 40-50 Tg C/year in India [134], 119-236 Tg C/year in China [135], 300 Tg C/year in the USA [136] and 6-10 Tg C/year in Kenya [137].

Similar to cropland, there are also recommended grazing systems that can enhance both SOC and the terrestrial $\mathrm{C}$ pools. It is widely recognized that high stocking rates and other indiscriminate practices underlie much of the degradation of grazing lands [138]. It is thus important to avoid high stocking rates, because they adversely affect soil physical quality, increase soil erosion risks and reduce biomass productivity [139]. Therefore, rehabilitation of degraded rangelands is an important option to increase soil and terrestrial $\mathrm{C}$ pools. Exclosures, keeping animals off the land, can be effective in restoring vegetation, reducing soil erosion hazard and improving soil fertility [125]. Therefore, degraded grazing lands must be protected by implementing exclosures through objective consideration of socio-economic and policy issues.

\section{Precision Agriculture}

Precision agriculture (PA) or soil/site-specific technology includes a set of practices that are based on appropriate combination of sensors, information technology, appropriate machinery and other RMPs designed to optimize the use of inputs on the basis of variability in soil properties and other attributes of the landscape that affect agronomic production [140]. These technologies based on specific soil/animal/tree units optimize resource use, minimize the environmental footprint and improve production. The strategy is to monitor the lifecycle and optimize resource use at every step of the production chain. However, the low adoption rate of PA technology is attributed to a range of factors [141]: (i) socio-economic factors, such as operator age, years of formal education, years of farming experience, farmer perception/mindset, land tenure, farm size and financial status; (ii) agroecological factors comprised of climate, biome, soil quality and its assessment, nutrient reserves and availability, soil moisture content and its spatial variability, soil erodibility and the top soil depth; (iii) institutional factors, including infrastructure, access to the market, extension services and information availability, farm location and proximity to a road or railway line; and (90) technological factors, such as irrigation, computers, etc. Therefore, policy interventions must be identified to address the limiting factor(s).

The adoption of PA technology can also reduce the risk of non-point source pollution. Human activities have mobilized $\sim 0.5 \mathrm{Pg}$ of $\mathrm{P}$ from rocks into the aquatic ecosystems since about 1950 [142], along with the attendant pollution of water resources. Closing the human P cycle [143] may be an option to addressing the issue of peak $\mathrm{P}$ and to avert $\mathrm{P}$ crisis [144]. This is where the adoption of PA can be useful. Similarly, precision tillage or guided traffic can reduce the risk of soil compaction. Permanent raised beds, designed to improve soil structure and yield [133], are also a form of PA.

\section{Sustainable Management}

Subsistence farming, widely practiced by small landholders in developing countries, leads to negative soil nutrient balances, because of the mining of soil fertility [145]. Sustainable management of macro- and micro-nutrients is essential to improving productivity, but also enhancing human nutrition [146]. Agronomic regeneration of soil fertility in Asian smallholder uplands is essential to 
sustainable food production [147]. Affordable nutrient solutions have to be developed for improving food security [148] and eliminating nutrient imbalances [149]. Regeneration of soil fertility, through integrated nutrient management (INM), is critical to improving the agronomic productivity of smallholder farmers of Asia [147] and elsewhere in developing countries, including SSA. Important components of INM include the use of animal manure, green manures, BNF and judicious use of chemical fertilizers. There are also future prospects for cereals that may fix $\mathrm{N}$ [150]. There exists a close link between food and biodiversity [58], and trees can be closely linked with croplands. Fertilizer trees, grown as agroforestry systems, can restore soil fertility and productivity. Akinnifesi et al. [112] reported that some fertilizer trees can add up to $60 \mathrm{~kg} \mathrm{~N} / \mathrm{ha} / \mathrm{yr}$, reduce the need for mineral fertilizers by $75 \%$ and substantially increase crop yield. In some conditions (East and Southern Africa), the use of fertilizer trees can double maize yield and, thus, enhance profit and net returns [112]. Some commonly used fertilizer trees include Faidherbia, Gliricidia, Leucaena, Sesbania, perennial pigeon pea, acacia, Tephrosia and numerous others. Trading $\mathrm{C}$ credits (soil $\mathrm{C}$ and biomass $\mathrm{C}$ ) would create another income stream [151] and promote the adoption of RMPs.

\section{Urban Agriculture}

Urban agriculture has been used in historic times by several prominent ancient civilizations. Among others, two examples include the Classic Maya civilization of the late first millennium AD in Central America and Byzantine Constantinople (Greek-speaking continuation of the Roman Empire during the late antiquity and the Middle ages) [152]. Therefore, localized food systems are also widely considered as a way towards sustainable livelihoods and ecological security [153]. Indeed, rapid urbanization in China (and elsewhere in Asia) is a real challenge to food security [154] where urban agriculture can play a crucial role. Therefore, there is a growing interest in smart cities [155] and vertical farms [156]. The latter implies controlled environment agriculture, greenhouse technologies, stacking buildings on top of each other to grow food, etc.

More than $50 \%$ of the world's population is already urbanized. However, at present, there are large differences among continents with regards to urbanization [157]. Similar to rural areas, there are problems of food insecurity and malnutrition in urban centers. Mega cities have to be fed by bringing into the cities thousands of $\mathrm{Mg}$ of food on a daily basis, the food-mileage for long-distance transport creates a large energy footprint. Thus, urban food production is also an important strategy for recycling wastewater and other biosolids. In addition to home gardens, there are potentials for rooftop gardens and other opportunities [158]. Urban agriculture is a 'niche production' with production sites comprised of abandoned homes and factories, road strips and riverbanks, lakes and home gardens [157]. Urban agriculture, growing globally, is also important to economic development and job creation, in addition to advancing food security. The use of green roof technology is gaining momentum [159] (Figure 6). Properly implemented green roof technology could facilitate the use of formal space and water use, promote just use of ground level resources and minimize the use of contaminated land and polluted water, thereby reducing health risks (e.g., heavy metals) [159]. It is widely believed that urban gardens, agriculture and water management have a large potential to advance food security [152]. Consequently, several case studies have been conducted to promote urban agriculture, including manure management in urban and peri-urban livestock units in West African cities [160], potential and observed 
food flows in Tianjin, China [161] and the emergence of urban agriculture in Sydney, Australia [162], and cities in East and West Africa [163].

There are several researchable issues in urban agriculture that need to be addressed, especially with regards to some agronomic constraints that are unique to urban agriculture. Important among these are water availability, soil fertility, soil compaction and soil pollution. The impact of urban agriculture on eco-cycles, poverty alleviation and small mixed crop-livestock farms need to be critically assessed [163]. There is a need to study the importance and management of community gardens in developed/modern cities in North America, Europe and elsewhere [164].

Figure 6. A well-established roof garden at The Wilds, Muskingum County, Ohio, USA.

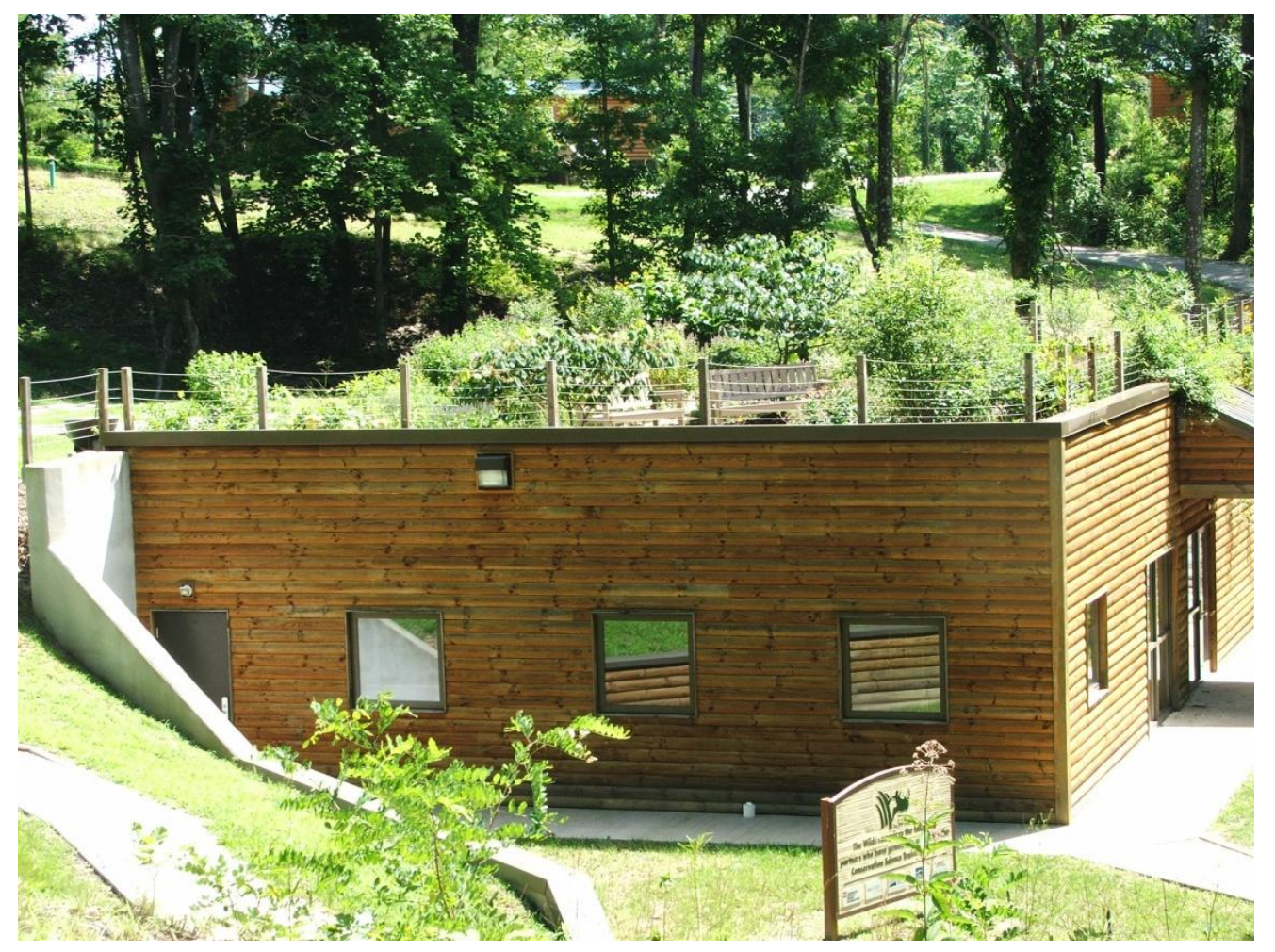

\section{Biofuels}

Climate change and the increase in energy demand globally are among numerous reasons for the growing emphasis on biofuels. Nonetheless, biofuels remain a debatable issue, because of the competition with food production for water, nutrients, land, the Ecosystem Carbon Payback Times [165] and the related socio-economic issues [166]. It is also questionable whether carbon-negative biofuels can be produced from low-input, high-diversity grassland systems [88]. Other issues include the geographic distribution of resources, the food $v$ s. fuel debate, environmental effects and emissions [167]. There are issues that regard ecological economics and sustainability science [167]. Thus, there is a need for the development of sustainable biofuels criteria to promote a shift away from biofuels based on food grains (corn, soybeans). Identification of sustainable feedstock and their production practices is a high priority. 


\section{Meat-Based Diet}

Similar to biofuel, the meat-based diet is also an important issue. The question "could less meat mean more food" [168] must be critically reviewed. The protein efficiency per unit energy and per unit GHG emissions is the principal concern. Animal-based foods are associated with higher energy use and GHG emissions than plant-based foods, except for the vegetables produced in heated greenhouses in Scandinavia [169]. The increasing world consumption of beef is also considered to be a major driver of regional and global climate change [170]. The non-vegetarian diet may require 2.9 times more water, 2.5 times more primary energy, 13 times more fertilizer and 1.4 times more pesticides [171]. Consumption of beef is the single most important factor responsible for the large difference in environmental footprint between the vegetarian and the meat-based diet. Thus, the possibility of producing beef from stem cells [172] may be an important development. Production in laboratory, etc., is also important, because $83 \%$ of the average household footprint of $8.1 \mathrm{Mg} \mathrm{CO}_{2} \mathrm{e} / y e a r$ is attributed to the production of food despite the long-distance transport (food miles) estimated at 1,640 km for delivery and 6,760 $\mathrm{km}$ for the lifecycle (LC) supply chain [173]. Yet, transportation accounts for merely $11 \%$ of the LC emissions of GHGs compared with an additional $4 \%$ from the producer to retail stores [173].

Dietary preferences strongly affect GHG emissions and contribute towards the risks of food insecurity directly, because of competition for grains, etc., and indirectly through climate change related to emission of GHGs. There is a large difference in GHG emissions among food materials, ranging from 0.4 to $30 \mathrm{~kg} \mathrm{CO}_{2} \mathrm{e} / \mathrm{kg}$ edible product [174]. Thus, promoting a plant-based diet is an important strategy to advance global food security and to reduce the risks of climate change. Indeed, a switch to plant-based protein food could save up to 2,700 Mha of pastureland and 100 Mha of cropland for restoration and setting aside [59] the land, which could be used for nature conservancy. These land savings would also reduce emissions of nitrous oxide $\left(\mathrm{N}_{2} \mathrm{O}\right)$ and methane $\left(\mathrm{CH}_{4}\right)$. Gerbens-Leenes and Nonhebel [175] reported a difference of a factor of two between the land requirements for the predominant European food patterns, including six times more land for a meat-based than a wheat-based diet. Indeed, lifestyle and behavior changes at the household level could have a major impact on global land use and the projected climate change. Thus, any assessment of the global land requirements for meeting food demands must be based on food consumption patterns [176].

\section{Research and Developmental Needs towards Achieving Global Food Security}

The important role of agronomy in enhancing production sustainability while addressing complexity in food production and resource management [38] cannot be overemphasized. However, there is a strong need to radically rethink agriculture for the 21st Century [177]. In addition to enhancing food production through sustainable means, there are numerous options to reduce the demand by decreasing losses [178] and exploring other innovations. Precision agriculture has a vast potential to reduce the environmental footprint through [140]: (i) soils/site-specific application of inputs; (ii) livestock management; and (iii) standardization and food traceability. Site-specific adaptive research is needed to apply these concepts also to tree management, irrigation management, pest management and other inputs. The African Green Revolution is achievable [179] through the adoption of proven technology and the strengthening of human resources and institutional capacity. 
Proven technology, with a demonstrable outcome, must be scaled up in a manner that sustainably enhances productivity [126] in SSA. Soil degradation on smallholder farmers [180] and the control of wind erosion in the Sahel [181] must be addressed. Water scarcity, with close links to energy [182], may be exacerbated, because of extreme events, climate change and variability. Water scarcity may be severe in several river basins, including the Indus River [183]. Identifying sustainable alternative cropping systems to replace the water-demanding rice-wheat system currently practiced in the Indo-Gangetic Plains and in the semi-arid regions of China is a high priority. Sustainable agriculture is a good weapon for fighting climate change and transforming smallholders from victims to agents [184] of resilience. Adaptation and the mitigation of soil and water conservation measures by small-scale farming involving 2.5 billion people globally [185] are important strategies for SSA and elsewhere. The whole-farm analysis of cropping systems can be a useful tool to assess the economic sustainability [35]. Among plant nutrients, $\mathrm{P}$ is a special case. Despite uncertainties in estimates, the limited proven reserves may be depleted in 50 to 100 years [186,187], reinforcing the concerns of “peak P" [74]. Thus, novel maps of major crop groups and net primary productivity (NPP) [57] and of the status of soil/land degradation are needed to identify and implement restorative strategies. The goal is to halt agricultural expansion by bridging the yield gap [95] and adopting other measures (Figure 5). Reducing waste or losses is critical, and losses in the U.S. are estimated to be up $40 \%$ from "farm to fork to landfill" [188]. Indeed, large food losses and wasted resources globally are unacceptable [189]. The practicality and economics of green roof technology in the context of urban agriculture must be advanced [159]. Closing the yield gap in developing countries through promotion of modern innovations is essential [190,191]. Compaction caused by heavy machinery [192,193] and degradation by over grazing [194] must be addressed.

Hunger is also a problem in developed countries, such as the U.S. [195], which must also be addressed. The food security and environment dilemma necessitate a long-range plan at the continental level, such as the European Science plan [196]. Adaptation and mitigation strategies related to sustainable food consumption must be developed at the national level, such as those planned for the UK [197]. Improving soil quality is essential to advancing food security [198]. Radically rethinking of agriculture [199] and paradigm shift in land husbandry [200] is needed of the production chain. In addition to reducing productivity on-site, accelerated erosion can also exacerbate gaseous emission off-site [201]. Thus, an appropriate action towards global governance of soil resources is an essential condition of sustainable development [202].

\section{Conclusions}

A critical review of the available information supports the following conclusions:

(1) Global food production must be increased substantially over the next several decades, both to meet the demands of a growing population and for increasing preferences towards the animal-based diet.

(2) Global soil and water resources are limited, vulnerable to land misuse and soil mismanagement and strongly coupled with the processes that also govern climate change.

(3) Sustainable intensification of agriculture, based on proven technologies, can increase food, production on existing land, reverse the processes of soil and environmental degradation and 
avoid the encroachment on or conversion of natural ecosystems (e.g., forest, prairie) into agroecosystems.

(4) Conservation agriculture, precision agriculture water harvesting and recycling by micro-irrigation, agroforestry, urban agriculture and techniques of carbon sequestration in soils and ecosystems, perennial culture and integrated nutrient management based on biological nitrogen fixation are among the proven technologies of sustainable intensification.

(5) Important among researchable priorities are soil/site-specific identification of appropriate system-based agronomic packages, operationalizing urban agriculture and green roof technology, promoting precision agriculture and conservation agriculture and developing modus operandi for payments to land managers for ecosystem services (e.g., carbon farming).

\section{Conflicts of Interest}

The author declares no conflicts of interest.

\section{References}

1. Koning, N.B.J.; van Ittersum, M.K.; Becx, G.A.; van Boekel, M.A.J.S.; Brandenburg, W.A. Long-term global availability of food: Continued abundance or new scarcity? J. Life Sci. 2008, 55, 229-292.

2. Swinnen, J.; Squicciarini, P. Mixed messages on prices and food security. Science 2012, 335, 405-406.

3. Godfray, H.C.J.; Beddington, J.R.; Crute, I.R.; Haddad, L.; Lawrence, D. Food security: The challenge of feeding 9 billion people. Science 2010, 327, 812-818.

4. How to feed a hungry world. Nature 2010, 466, 531-532.

5. Parker, J. The 9 Billion-people Question: A Special Report on Feeding the World. Available online: http://www.economist.com/node/18200618 (accessed on 22 August 2013).

6. Lal, R. Soil degradation as a reason for inadequate human nutrition. Food Sec. 2009, 1, 45-57.

7. Lal, R.; Delgado, J.A.; Gulliford, J.; Nielsen, D.; Rice, C.W.; van Pelt, R.S. Adapting agriculture to drought and extreme events. J. Soil Water Conserv. 2012, 67, 162-166.

8. Lyall, S. Heat, Flood or Icy Cold, Extreme Weather Rages Worldwide; The New York Times: New York, NY, USA, 2013.

9. Parry, M.; Rosenzweig, C.; Livermore, M. Climate change, global food supply and risk of hunger. Phil. Trans. Roy. Soc. London B 2005, 360, 2125-2138.

10. Romm, J. Oxfam: Extreme Weather Has Helped Push Tens of Millions into Hunger and Poverty in Grim Foretaste of Warmed World. Available online: http://thinkprogress.org/climate/2011/11/29/377015/oxfam-extreme-weather-hunger-andpoverty/?mobile+=nc (accessed on 22 August 2013).

11. Greenhouse Gas Bulletin: The State of Greenhouse Gases in the Atmosphere Based on Global Observations through 2011; World Meteorological Organization (WMO): Geneva, Switzerland, $2011 ;$ p. 4. 
12. IPCC. Summary for Policymakers. In Climate Change 2013: The Physical Science Basis. Contribution of Working Group I to the Fifth Assessment Report of the Intergovernmental Panel on Climate Change; Stocker, T.F., Qin, D., Plattner, G.-K., Tignor, M., Allen, S.K., Boschung, J., Nauels, A., Xia, Y., Bex, V., Midgley, P.M., Eds.; Cambridge University Press: Cambridge, UK and New York, NY, USA, 2013.

13. Lal, R. The Nexus of Soil, Water and Waste; UNU-FLORES: Dresden, Germany, 2013.

14. United Nations (UN). Population Division of the Department of Economic and Social Affairs of the United Nations Secretariat, World Population Prospects: The 2006 Revision and World Urbanization Prospects: The 2007 Revision, 2012. Available online: http://esa.un.org/unup (accessed on 22 August 2013).

15. Energy Information Agency, USA (EIA). Annual Energy Outlook 2013 with Projections to 2040. Available online http://www.eia.gov/forecasts/aeo/pdf/0383(2013).pdf (accessed on 26 November 2013).

16. Ehrlich, P.R.; Holdren, J.P. Impact of population growth. Science 1974, 171, 1212-1217.

17. Pimentel, D. Food for thought: A review of the role of energy in current and evolving agriculture. Crc Crit. Rev. Plant Sci. 2011, 30, 35-44.

18. Flora, C.B. Food security in the context of energy and resource depletion: Sustainable agriculture in developing countries. Renew. Agr. Food Syst. 2010, 25, 118-128.

19. Rosegrant, M.W.; Paisner, M.S.; Meijer, S.; Witcover, J. 2020 Global Food Outlook: Trends, Alternatives, and Choices. Available online: http://www.fcrn.org.uk/sites/default/files/ fpr30_0.pdf (accessed on 22 August 2013).

20. Swaminathan, M.S. Combating hunger. Science 2012, 338, 1009.

21. Lovejoy, S. What is climate? EOS 2013, 94, 1-2.

22. Lovejoy, S.; Schertzer, D.; Varon, D. Do GCM's predict the climate or macroweather? Earth Syst. Dyn. Discuss. 2012, 3, 1259-1286.

23. Zhang, J. China's success in increasing per capita food production. J. Exp. Bot. 2011, 62, 3707-3711.

24. Miao, Y.; Stewart, R.A.; Zhang, F. Long-term experiments for sustainable nutrient management in China: A review. Agron. Sust. Dev. 2011, 31, 397-414.

25. Wild, A. Soils, Land and Food: Managing the Land during the 21st Century; Cambridge University Press: Cambridge, UK, 2003; p. 256.

26. Blanco-Canqui, H.; Lal, R. Corn stover removal impacts on micro-scale soil physical properties. Geoderma 2008, 145, 335-346.

27. Lashgarara, F.; Mirdamadi, S.M.; Hosseini, S.J.F.; Chizari, M. The Role of Food-security Solutions in the Protection of Natural Resources and Environment of Developing Countries. In Environmental Challenges in the Pacific Basin Book Series: Annals of the New York Academy of Sciences; Carpenter, D., Ed.; Wiley-Blackwell: Hoboken, NJ, USA, 2008; pp 68-72.

28. Bouma, J.; Mcbratney, A. Framing soils as an actor when dealing with wicked environmental problems. Geoderma 2013, 200, 130-139.

29. International Assessment of Agricultural Knowledge, Science and Technology for Development (IAASTD). Agriculture at A Crossroads: Synthesis Report. Available online: http://www.unep.org/dewa/agassessment/reports/iaastd/en/agriculture\%20at\%20a\%20crossroads _synthesis\%20report\%20(english).pdf (accessed on 25 December 2013). 
30. Commission on Sustainable Agriculture and Climate Change. Achieving Food Security in the Face of Climate Change; Beddington, J., Asaduzzaman, M., Clark, N., Eds.; Institute of Development Studies, University of Sussex: Brighten, UK, 2012.

31. Climate Change and Hunger: Responding to the Challenge; World Food Programme: Rome, Italy, 2009; p. 100.

32. Battisti, D.S.; Naylor, R.L. Historical warnings of future food insecurity with unprecedented seasonal heat. Science 2009, 323, 240-244.

33. Nelson, G.C.; Rosegrant, M.W.; Koo, J.; Robertson, R.; Sulser, T.; Zhu, T.; RIngler, C.; Msangi, S.; Palazzo, A.; Batka, M.; Magalhaes, M.; Valmonte-Santos, R.; Ewing, M.; Lee, D. Climate Change: Impact on Agriculture and Costs of Adaptation. Food Policy Report; International Food Policy Research Institute: Washington, DC, USA, 2009.

34. Lenka, N.K.; Lal, R. Soil-related constraints to the carbon dioxide fertilization effect. Crc Crit. Rev. Plant Sci. 2012, 31, 342-357.

35. Yiridoe, E.K.; Langyintuo, A.S.; Dogbe, W. Economics of the impact of alternative rice cropping systems on subsistence farming: Whole-farm analysis in northern Ghana. Agr. Syst. 2006, 91, 102-121.

36. Tyfield, D. Food systems transition and disruptive low carbon innovation: Implications for a food security research agenda. J. Exp. Bot. 2011, 62, 3701-3706.

37. Fan, M.; Shen, J.; Yuan, L.; Jiang, R.; Chen, X. Improving crop productivity and resource use efficiency to ensure food security and environmental quality in China. J. Exp. Bot. 2012, 63, 13-24.

38. Spiertz, H. Avenues to meet food security. The role of agronomy on solving complexity in food production and resource use. Eur. J. Agron. 2012, 43, 1-8.

39. Rockström, J.; Barron, J. Water productivity in rainfed systems: Overview of challenges and analysis of opportunities in water scarcity prone savannahs. Irrig. Sci. 2007, 25, 299-311.

40. Crews, T.E.; Peoples, M.B. Legume vs. fertilizer sources of nitrogen: Ecological tradeoffs and human needs. Agr. Ecosyst. Environ. 2004, 102, 279-297.

41. Revelle, R. Carbon dioxide and world climate. Sci. Amer. 1982, 247, 35, 39-40.

42. Revelle, R. The resources available for agriculture. Sci. Amer. 1976, 235, 165-178.

43. Adgo, E.; Teshome, A.; Mati, B. Impacts of long-term soil and water conservation on agricultural productivity: The case of anjenie watershed, Ethiopia. Agr. Water Manage. 2013, 117, 55-61.

44. Dregne, H.E. Desertification: Challenges ahead. Ann. Arid Zone 1996, 35, 305-311.

45. Oldeman, L.R. The Global Extent of Soil Degradation. In Soil Resilience and Sustainable Land Use Greeland; Szabolcs, I.D.J., Ed.; Cab International: Wallingford, UK, 1994; pp 99-118.

46. Bai, Z.G.; Dent, D.L.; Olsson, L.; Schapman, M.E. Proxy global assessment of land degradation. Soil Use Manage. 2008, 24, 223-234.

47. Jenerette, G.D.; Lal, R. Hydrologic sources of carbon cycling uncertainty throughout the terrestrial aquatic continuum. Glob. Change Biol. 2006, 11, 1852-1873.

48. Lal, R. Enhancing eco-efficiency in agroecosystems through soil C sequestration. Crop Sci. 2010, 50, S120-S131.

49. Den Biggelaar, C.; Lal, R.; Wiebe, K.; Breneman, V. The global impact of soil erosion on productivity. II. Effects on crop yields and production over time. Advan. Agron. 2004, 81, 49-95. 
50. Lal, R. Soil erosion impact on agronomic productivity and environmental quality. Crc Crit. Rev. Plant Sci. 1998, 17, 319-464.

51. Lal, R. Effects of soil erosion on crop productivity. Crc Crit. Rev. Plant Sci. 1987, 5, 303-368.

52. Eynard, A.; Lal, R.; Wiebe, K. Crop response in salt-affected soils. J. Sustainable Agr. 2005, 27, doi:10.1300/J064v27n01_03.

53. Tan, Z.; Lal, R.; Wiebe, K. Soil nutrient depletion and global yield reduction. J. Sust. Agric. 2005, 26, 123-146.

54. Lal, R. Long-term tillage and wheel traffic effects on soil quality for two central Ohio soils. $J$. Sustainable Agr. 1999, 14, 67-84.

55. Nkonya, E.; Gerber, N.; Baumgartner, P.; von Braun, J.; de Pinto, A.; Graw, V.; Kato, E.; Kloos, J.; Walter, T. The Economics of Land Degradation: Towards an Integrated Global Assessment. Development Economics and Policy. Band 66; Peter Lang: Berlin, Germany, 2011; p. 262.

56. Lobell, D.B.; Cassman, K.G.; Field, C.B. Crop yield gaps: Their importance, magnitudes, and causes. Annu. Rev. Environ. Resour. 2009, 34, 179-204.

57. Monfreda, C.; Ramankutty, N.; Foley, J.A. Farming the planet: Geographic distribution of crop areas, yields, physiological types, and net primary production in the year 2000. Global Biogeochem. Cycle. 2008, 22. doi: 10.1029/2007GB002952.

58. Godfray, H.C.J. Food and biodiversity. Science 2011, 333, 1231-1232.

59. Stehfest, E.; Bouwman, L.; van Vuuren, D.P.; den Elzen, M.G.J.; Eickhout, B. Climate benefits of changing diet. Climate Change 2009, 95, 83-102.

60. Fernandez, M. Texas Bakes in a Long Drought, Water Becomes Focus for Legislators; New York Times International: New York, NY, USA, 2013.

61. Gills, J. Not Even Close: 2012 was Hottest Even in USA; New York Times International: New York, NY, USA, 2013.

62. Koebler, J. Report: 100 Million Could Die from Climate Change by 2030. Available online: http://www.usnews.com/news/articles/2012/09/27/report-100-million-could-die-from-climatechange-by-2030 (accessed on 22 August 2013).

63. Hatfield, J.L.; Boote, K.J.; Kimball, B.A.; Ziska, L.H.; Izaurralde, R.C. Climate impacts on agriculture: Implications for crop production. Agron. J. 2011, 103, 351-370.

64. Gregory, P.J.; Ingram, J.S.I.; Brklacich, M. Climate change and food security. Phil. Trans. Roy. Soc. London B 2005, 360, 2139-2148.

65. Newton, A.C.; Johnson, S.N.; Gregory, P.J. Implications of climate change for diseases, crop yields and food security. Euphytica 2011, 179, 3-18.

66. Funk, C.C.; Brown, M.E. Declining global per capita agricultural production and warming oceans threaten food security. Food Secur. 2009, 1, 271-289.

67. Haile, M. Weather patterns, food security and humanitarian response in Sub-Saharan Africa. Phil. Trans. Roy. Soc. London B 2005, 360, 2169-2182.

68. Armah, F.A; Odoi, J.O.; Yengoh, G.T.; Obiri, S.; Yawson, D.O. Food security and climate change in drought-sensitive savanna zones of Ghana. Mitigation Adaptation Strateg. Glob. Change 2011, 16, 291-306. 
69. Kotir, J.H. Climate change and variability in Sub-Saharan Africa: A review of current and future trends and impacts on agriculture and food security. Environ. Dev. Sustain. 2011, 13, 587-605.

70. Kurukulasuriya, P.; Mendelsohn, R.; Hassan, R.; Benhin, J.; Deressa, T.; Diop, M.; Eid, H.M.; Fosu, K.Y.; Gbetibouo, G.; Jain, S.; et al. Will African agriculture survive climate change? World Bank Econ. Rev. 2006, 20, 367-388.

71. Challinor, A.; Wheeler, T.; Garforth, C.; Craufurd, P.; Kassam, A. Assessing the vulnerability of food crop systems in Africa to climate change. Climate Change 2007, 83, 381-399.

72. Liu, J.; Fritz, S.; van Wesenbeeck, C.F.A.; Fuchs, M.; You, L. A spatially explicit assessment of current and future hotspots of hunger in Sub-Saharan Africa in the context of global change. Global Planet. Change 2008, 64, 222-235.

73. Moore, N.; Alagarswamy, G.; Pijanowski, B.; Thornton, P.; Lofgren, B. East African food security as influenced by future climate change and land use change at local to regional scales. Climate Change 2012, 110, 823-844.

74. Brown, L.R. Who will feed China? Futurist 1996, 30, 14-18.

75. Ye, L.; van Ranst, E. Production scenarios and the effect of soil degradation on long-term food security in China. Global Environ. Change 2009, 19, 464-481.

76. Tao, F.; Yokozawa, M.; Liu, J.; Zhang, Z. Climate change, land use change, and China's food security in the 21st Century: An integrated perspective. Climate Change 2009, 93, 433-445.

77. Beddington, J. Global food and farming futures. Phil. Trans. Roy. Soc. London B 2010, 365, 2767. doi: 10.1098/rstb.2010.0181

78. Beddington, J. Food security: Contributions from science to a new and greener revolution. Phil. Trans. Roy. Soc. London B 2010, 365, 61-71.

79. HLPE. Food Security and Climate Change. Available online: http://www.fao.org/docrep/ meeting/026/me495e.pdf (accessed on 22 August 2013).

80. Fischer, G.; van Velthuizen, H.; Hizsnyik, E.; Wiberg, D. Potentially Obtainable Yields in the Semiarid Tropics. Global Theme on Agroecosystems. Available online: http://oar.icrisat.org/198/ (accessed on 25 November 2013).

81. Licker, R.; Johnston, M.; Foley, J.A.; Barford, C.; Kucharik, C.J. Mind the gap: How do climate and agricultural management explain the "yield gap" of croplands around the world? Global Ecol. Biogeogr. 2010, 19, 769-782.

82. Laborte, A.G.; de Bie, K.C.A.J.M.; Smaling, E.M.A.; Moya, P.F.; Boling, A. Rice yields and yield gaps in southeast Asia: Past trends and future outlook. Eur. J. Agron. 2012, 36, 9-20.

83. Van Tran, D. Closing the Rice Yield Gap for Food Security. In The New Development in Rice Agronomy and Its Effects on Yield and Quality in Mediterranean Areas; Chataigner, J., Ed.; CIHEAM: Montpellier, France, 2001; pp. 2-12.

84. Ingram, J.S.I.; Gregory, P.J.; Izac, A.-M. The role of agronomic research in climate change and food security policy. Agr. Ecosyst. Environ. 2008, 126, 4-12.

85. Wopereis, M.C.S.; Defoer, T. Moving Methodologies to Enhance Agricultural Productivity of Rice-based Lowland Systems in Sub-Saharan Africa; In Advances in Integrated Soil Fertility Management in Sub-Saharan Africa: Challenges and Opportunities; Bationo, A., Waswa, B., Kihra, B., Eds.; Springer: New York, NY, USA, 2007; pp. 1077-1091. 
86. Antle, J.M.; Capalbo, S.M. Adaptation of agricultural and food systems to climate change: An economic and policy perspective. Appl. Econ. Perspect. Policy 2010, 32, 386-416.

87. Tilman, D.; Balzer, C.; Hill, J.; Befort, B.L. Global food demand and the sustainable intensification of agriculture. Proc. Natl. Acad. Sci. USA 2011, 108, 20260-20264.

88. Tilman, D.; Hill, J.; Lehman, C. Carbon-negative biofuels from low-input high-diversity grassland biomass. Science 2006, 314, 1598-1600.

89. Lobell, D.B.; Burke, M.B.; Tebaldi, C.; Mastrandrea, M.D.; Falcon, W.P. Prioritizing climate change adaptation needs for food security in 2030. Science 2008, 319, 607-610.

90. Alauddin, M.; Quiggin, J. Agricultural Intensification, irrigation and the environment in south Asia: Issues and policy options. Ecol. Econ. 2008, 65, 111-124.

91. Vermeulen, S.J.; Aggarwal, P.K.; Ainslie, A.; Angelone, C.; Campbell, B.M. Options for support to agriculture and food security under climate change. Environ. Sci. Policy 2012, 15, 136-144.

92. Burney, J.A.; Davis, S.J.; Lobell, D.B. Greenhouse gas mitigation by agricultural intensification. Proc. Natl. Acad. Sci. USA 2010, 107, 12052-12057.

93. Kreye, C.; Bouman, B.A.M.; Reversat, G.; Fernandez, L.; Cruz, C.V. Biotic and abiotic causes of yield failure in tropical aerobic rice. Field Crop. Res. 2009, 112, 97-106.

94. Kreye, C.; Bouman, B.A.M.; Castaneda, A.R.; Lampayan, R.M.; Faronilo, J.E. Possible causes of yield failure in tropical aerobic rice. Field Crop. Res. 2009, 111, 197-206.

95. Foley, J.A.; Ramankutty, N.; Brauman, K.A.; Cassidy, E.S.; Gerber, J.S. Solutions for a cultivated planet. Nature 2011, 478, 337-342.

96. Sanchez, P.A. Tripling crop yields in tropical Africa. Nat. Geosci. 2010, 3, 299-300.

97. Glover, J.D.; Reganold, J.P.; Bell, L.W.; Borevitz, J.; Brummer, E.C. Increased food and ecosystem security via perennial grains. Science 2010, 328, 1638-1639.

98. Ziska, L.H.; Bunce, J.A.; Shimono, H.; Gealy, D.R.; Baker, J.T. Food security and climate change: On the potential to adapt global crop production by active selection to rising atmospheric carbon dioxide. Proc. Biol. Sci. 2012, 279, 4097-4105.

99. O'Mara, F.P. The role of grasslands in food security and climate change. Ann. Bot. 2012, 110, 1263-1270.

100. Gill, M.; Smith, P.; Wilkinson, J.M. Mitigating climate change: The role of domestic livestock. Animal 2010, 4, 323-333.

101. The Potential of USA Grazing Lands to Sequester Carbon and Mitigate the Greenhouse Effect; Follett, R.F., Kimble, J.M., Lal, R., Eds.; CRC Press LLC.: Boca Raton, FL, USA, 2011; p. 472.

102. Lal, R., Stewart, B.A. Principles of Sustainable Soil Management in Agroecosystems. In Advances in Soil Science; Lal, R., Stewart, B.A., Eds;. Taylor and Francis: Boca Raton, FL, USA, 2013; p. 568.

103. Lal, R. Constraints to adopting no-till farming in developing countries. Soil Till. Res. 2007, 94, 1-3.

104. Lal, R. Controlling Greenhouse Gases and Feeding the World through Soil Management, Distinguished University Lecture; The Ohio State University: Columbus, OH, USA, 2000.

105. Shah, T.; Singh, O.; Mukherji, A. Some aspects of south asia's groundwater irrigation economy: Analyses from a survey in India, Pakistan, Nepal Terai and Bangladesh. Hydrogeol. J. 2006, 14, 286-309. 
106. Condon, A.G.; Richards, R.A; Rebetzke, G.J.; Farquhar, G.D. Improving intrinsic water-use efficiency and crop yield. Crop Sci. 2002, 42, 122-131.

107. Bossio, D.; Geheb, K.; Critchley, W. Managing water by managing land: Addressing land degradation to improve water productivity and rural livelihoods. Agr. Water Manage. 2010, 97, 536-542.

108. Aldaya, M.M.; Allan, J.A.; Hoekstra, A.Y. Strategic importance of green water in international crop trade. Ecol. Econ. 2010, 69, 887-894.

109. Cassman, K.G.; Ecological intensification of cereal production systems: Yield potential, soil quality, and precision agriculture. Proc. Natl. Acad. Sci. 1999, 96, 5952-5959.

110. Monaghan, J.M.; Daccache, A.; Vickers, L.H.; Hess, T.M.; Weatherhead, E.K. More "crop per drop": Constraints and opportunities for precision irrigation in European agriculture. J. Sci. Food Agr. 2013, 93, 977-980.

111. Wilkinson, S.; Davies, W.J. Drought ozone, aba, and ethylene: New insight from cell plant community. Plant Cell Environ. 2010, 35, 510-525.

112. Akinnifesi, F.K.; Ajayi, O.C.; Sileshi, G.; Chirwa, P.; Chianu, J. Fertiliser Trees for Sustainable Food Security in the Maize-based Production Systems of East and Southern Africa. In Sustainable Agriculture Lichtfouse, E., Hamelin, M.E., Navarrete, M., Debaeke, P., Eds.; Springer: Verlag, Netherlands, 2011; Volume 2, pp. 129-146.

113. Biazin, B.; Sterk, G.; Temesgen, M.; Abdulkedir, A.; Stroosnijder, L. Rainwater harvesting and management in rainfed agricultural systems in Sub-Saharan Africa-A review. Phys. Chem. Earth 2012, 47-48, 139-151.

114. Bouman, B.A.M.; Lampayan, R.M.; Toung, T.P. Water Management in Irrigated Rice: Coping with Water Scarcity. Available online: http://books.irri.org/9789712202193_content.pdf (accessed on 25 December 2013).

115. Bouman, B.A.M.; Peng, S; Castaneda, A.R.; Visperas, R.M. Yield and water use of irrigated tropical aerobic rice systems. Agr. Water Manage. 2005, 74, 87-105.

116. Yang, X; Bouman, B.A.M.; Wang, H.; Wang, Z.; Zhao, J.; Chen, B. Performance of temperate aerobic rice under different water regimes in north China. Agric. Water Manage. 2005, 74, $107-$ 122.

117. Yang, X.G.; Bouman, B.A.M.; Deng, W.; Zhang, Q.P. Effects of irrigation and nitrogen on the performance of aerobic rice in northern China. J. Integr. Plant Bio 2008, 50:12, 1589-1600.

118. Peng, S.; Bouman, B; Visperas, R.A.; Castañeda, A.; Nie, L.X.; Park, H.K. Comparison between aerobic and flooded rice in the tropics: Agronomic performance in an eight-season experiment. Field Crop. Res. 2006, 96, 252-259.

119. Xue, C.-Y.; Yang, X.-G.; Bouman, B.A.M.; Deng, W.; Zhang, Q.-P.; Yan, W.; Zhang, T.; Rouzi, A.; Wang, H. Optimizing yield, water requirements, and water productivity of aerobic rice for the north China plain. Irrig. Sci. 2008, 26, 459-474.

120. Bouman, B.A.M. Water-efficient Management Strategies in Rice Production. International Rice Research Notes 16.2; IRRI: Los Banos, Phillipines, 2001; pp. 17-22.

121. Zhang, L.; Lin, S.; Bouman, B.A.M.; Xue, C.; Wei, F. Response of aerobic rice growth and grain yield to $\mathrm{N}$ fertilizer at two contrasting sites near Beijing, China. Field Crop. Res. 2009, 114, 45-53. 
122. Nie, L.; Peng, S.H.; Bouman, B.A.M.; Huang, J.; Cui, K. Alleviating soil sickness caused by aerobic monocropping: Responses of aerobic rice to nutrient supply. Field Crop. Res. 2008, 107, 129-136.

123. Nie, L.; Peng, S.; Bouman, B.A.M.; Huang, J.; Cui, K.; Visperas, R.M.; Park, H.K. Alleviating soil sickness caused by aerobic monocropping: responses of aerobic rice to soil oven-heating. Plant Soil 2007, 300, 185-195.

124. Fan, S.; Chan-Kang, C. Is small beautiful? Farm size, productivity, and poverty in Asian agriculture. Agr. Econ. 2005, 32, 135-146.

125. Makurira, H.; Savenije, H.HG.; Uhlenbrook, S.; Rockstrom, J.; Senzanje, A. The effect of system innovations on water productivity in subsistence rainfed agr sys in semi-arid Tanzania. Agr. Water Manage. 2011, 98, 1696-1703.

126. Jama, B.; Pizarro, G. Agriculture in Africa: Strategies to improve and sustain smallholder production systems. Reducing the impact of poverty on health and human development. Sci. Approaches 2008, 1136, 218-232.

127. Lal, R.; Griffin, M.; Apt, J.; Lave, L.; Morgan, M.G. Managing soil carbon. Science 2004, 304, 393.

128. Lal, R. Soil carbon sequestration impacts on global climate change and food security. Science 2004, 304, 1623-1627.

129. Blanco-Canqui, H.; Lal, R. No-tillage and soil carbon sequestration: An on-farm assessment. Soil Sci. Soc. Amer. J. 2008, 72, 693-701.

130. Lal, R. A soil suitability guide for different tillage systems in the tropics. Soil Till. Res. 1985, 5, 179-196.

131. Toliver, D.K.; Larson, J.A.; Roberts, R.K.; English, B.C.; Ugarte, T.D.G. Effects of no-till on yields as influenced by crop and environmental factors. Agron. J. 2012, 104, 530-541.

132. Labreuche, J.; Lellahi, A.; Malaval, C.; Germon, J.-C. Impact of no-tillage agricultural methods on the energy balance and the greenhouse gas balance of cropping systems. Cah. Agric. 2011, $20,204-215$.

133. He, J.; McHugh, A.D.; Li, H.W.; Wang, Q.J.; Li, W.Y. Permanent raised beds improved soil structure and yield of spring wheat in arid north-western China. Soil Use Manage. 2012, 28, 536-543.

134. Lal, R. Soil carbon sequestration in India. Climatic Change 2004, 65, 277-296.

135. Lal, R. Offsetting China's $\mathrm{CO}_{2}$ emissions by soil carbon sequestration. Climatic Change 2004, 63, 263-275.

136. Lal, R.; Follett, R.F.; Stewart, B.A.; Kimble, J.M. Soil carbon sequestration to mitigate climate change and advance food security. Soil Sci. 2007, 172, 943-956.

137. Batjes, N.H. Soil carbon stocks and projected changes according to land use and management: A case study for Kenya. Soil Use Manage. 2004, 20, 350-356.

138. Keay-Bright, J.; Boardman, J. The influence of land management on soil erosion in the sneeuberg mountains, central Karoo, South Africa. Land Degrad. Dev. 2007, 18, 423-439.

139. Savadaogo, P.; Sawadogo, L.; Tiveau, D. Effects of grazing intensity and prescribed fire on soil physical and hydrological properties and pasture yield in the savanna woodlands of burkina faso. Agr. Ecosyst. Environ. 2007, 118, 80-92.

140. Gebbers, R.; Adamchuk, V.I. Precision agriculture and food security. Science 2010, 327, 828-831. 
141. Tey, Y.S.; Brindal, M. Factors influencing the adoption of precision agricultural technologies: A review for policy implications. Precis. Agric. 2012, 13, 713-730.

142. Cordell, D.; Rosemarin, A.; Schroder, J.J.; Smit, A.L. Towards global phosphorus security: A systems framework for phosphorus recovery and reuse options. Chemosphere 2011, 84, 747-758.

143. Childers, D.L.; Corman, J.; Edwards, M.; Elser, J.J. Sustainability challenges of phosphorus and food: Solutions from closing the human phosphorus cycle. Bioscience 2011, 61, 117-124.

144. Abelson, P.H. A potential phosphate crisis. Science 1999, 283, 2015.

145. Berkhout, E.D.; Schipper, R.A.; van Keulen, H.; Coulibaly, O. Heterogeneity in farmers' production decisions and its impact on soil nutrient use: Results and implications from northern Nigeria. Agr. Syst. 2011, 104, 63-74.

146. Graham, R.D.; Welch, R.M.; Bouis, H.E. Addressing micronutrient malnutrition through enhancing the nutritional quality of staple foods, perspectives and knowledge gaps. Adv. Agron. 2001, 70, 77-142.

147. De Costa, W.; Sangakkara, U. Agronomic regeneration of soil fertility in tropical asian smallholder uplands for sustainable food production. J. Agric. Sci. 2006, 144, 111-133.

148. Van der Velde, M.; See, L.; You, L.; Balkovic, J.; Fritz, S. Affordable nutrient solutions for improved food security as evidenced by crop trials. PLoS One 2013, 8, doi: 10.1371/journal.pone.0060075.

149. Vitousek, P.M.; Naylor, R.; Crews, T.; David, M.B.; Drinkwater, L.E. Nutrient imbalances in agricultural development. Science 2009, 324, 1519-1520.

150. Beatty, P.H.; Good, A.G. Future prospects for cereals that fix nitrogen. Science 2011, 333, 416-417.

151. Kruppa, M.; Allan, A. Carbon Trading may be Ready for Its Next Act. Available online: http://www.nytimes.com/2011/11/14/business/energy-environment/carbon-trading-may-be-readyfor-its-next-act.html (accessed on 14 November 2011).

152. Barthel, S.; Isendahl, C. Urban gardens, agriculture, and water management: Sources of resilience for long-term food security in cities. Ecol. Econ. 2013, 86, 224-234.

153. Sahu, S.K. Localized food systems: The way towards sustainable livelihoods and ecological security-A review. J. Anim. Plant Sci. 2011, 21, 388-395.

154. Chen, J. Rapid urbanization in China: A real challenge to soil protection and food security. Catena 2007, 69, 1-15.

155. Schuetze, C.F. Pursuing a Vision: Green and Livable; The New York Times: New York, NY, USA, 2011.

156. Despommier, D. The vertical farm: Controlled environment agriculture carried out in tall buildings would create greater food safety and security for large urban populations. J. Consum. Prot. Food Saf. 2011, 6, 233-236.

157. Drescher, A.W. Food for the Cities: Urban Agricultures in Developing Countries. Available online: http://www.actahort.org/books/643/643_29.htm (accessed on 22 August 2013).

158. Ghosh, S. Food Production in Cities. Available online: http://www.actahort.org/books/ 643/643_30.htm (accessed on 22 August 2013).

159. Whittinghill, L.J.; Rowe, D.B. The role of green roof technology in urban agriculture. Renew. Agric. Food Syst. 2012, 27, 314-322. 
160. Diogo, R.V.C.; Schlecht, E.; Buerkert, A.; Rufino, M.C.; van Wijk, M.T. Increasing nutrient use efficiency through improved feeding and manure management in urban and peri-urban livestock units of a west African city: A scenario analysis. Agr. Syst. 2013, 114, 64-72.

161. Zhou, D.; Matsuda, H.; Hara, Y.; Takeuchi, K. Potential and observed food flows in a Chinese city: A case study of Tianjin. Agr. Hum. Values 2012, 29, 481-492.

162. Mason, D.; Knowd, I. The emergence of urban agriculture: Sydney, Australia. Int. J. Agr. Sustain. 2010, 8, 62-71.

163. Lee-Smith, D. Cities feeding people: An update on urban agriculture in equatorial Africa. Environ. Urban 2010, 22, 483-499.

164. Guitart, D.; Pickering, C.; Byrne, J. Past results and future directions in urban community gardens research. Urban Urban Green 2012, 11, 364-373.

165. Fargione, J.; Hill, J.; Tilman, D.; Polasky, S.; Hawthorne, P. Land clearing and the biofuel carbon debt. Science 2008, 319, 1235-1238.

166. Buerkert, A.; Schlecht, E. The biofuel debate-Status quo and research needs to meet multiple goals of food, fuel and ecosystem services in the tropics and subtropics. J. Agric. Rural Dev. Trop. Subtro. 2009, 110, 1-8.

167. Solomon, D.D. Biofuels and sustainability. Ann. N. Y. Acad. Sci. 2010, 1185, 119-134.

168. Stokstad, E. Could less meat mean more food? Science 2010, 327, 810-811.

169. Gonzalez, A.D.; Frostell, B.; Carlsson-Kanyama, A. Protein efficiency per unit energy and per unit greenhouse gas emissions: Potential contribution of diet choices to climate change mitigation. Food Policy 2011, 36, 562-570.

170. McAlpine, C.A.; Etter, A.; Fearnside, P.M.; Seabrook, L.; Laurance, W.F. Increasing world consumption of beef as a driver of regional and global change: A call for policy action based on evidence from Queensland (Australia), Colombia and Brazil. Global Environ. Change 2009, 19, 21-33.

171. Marlow, H.J.; Hayes, W.K.; Soret, S.; Carter, R.L.; Schwab, E.R. Diet and the environment: Does what you eat matter? Amer. J. Clin. Nutr. 2009, 89, S1699-S1703.

172. BBC. World's First Lab-Grown Hamburger is Eaten in London. Available online: http://www.bbc.co.uk/news/science-environment-23576143 (accessed on 28 August 2013).

173. Weber, C.L.; Matthews, H.S. Food-miles and the relative climate impacts of food choices in the United States. Environ. Sci.Technol. 2008, 42, 3508-3513.

174. Carlsson-Kanyama, A.; González, A.D. Potential contributions of food consumption patterns to climate change. Amer. J. Clin. Nutr. 2009, 89, S1704-S1709.

175. Gerbens-Leenes, P.W.; Nonhebel, S. Consumption patterns and their effects on land required for food. Ecol. Econ. 2002, 42, 185-199.

176. Gerbens-Leenes, P.W.; Nonhebel, S; Ivens, W.P.P.F. A method to determine land requirements relating to food consumption patterns. Agr. Ecosyst. Environ. 2002, 90, 47-58.

177. Fedoroff, N.Z.V.; Battisti, D.S.; Beachy, R.N.; Cooper, P.J.M.; Fischhoff, D.A.; Hodges, C.N.; Knauf, V.C.; Lobell, D.; Mazur, B.J.; Molden, D.; et al. Radically rethinking agriculture for the 21 st century. Science 2010, 327, 833-834.

178. Gustavsson, J.; Cederberg, C.; Sonesson, U.; Otterdijk, R.V.; Meybeck, A. Global Food Losses and Food Waste: Extent, Causes and Prevention; FAO: Rome, Italy, 2011; p. 29. 
179. Ejeta, G. African green revolution needn't be a mirage. Science 2010, 327, 831-832.

180. Nakhumwa, T.O.; Hassan, R.M. Optimal management of soil quality stocks and long-term consequences of land degradation for smallholder farmers in Malawi. Environ. Resour. Econ. 2012, 52, 415-433.

181. Sterk, G. Causes, consequences and control of wind erosion in Sahelian Africa: A review. Land Degrad. Dev. 2003, 14, 95-108.

182. Khan, S.; Hanjra, M.A. Footprints of Water and Energy Inputs in Food Production-Global perspectives. Food Policy 2009, 34, 130-140.

183. Qureshi, A.S. Water management in the Indus basin in Pakistan: challenges and opportunities. Mt. Res. Dev. 2011, 31, 252-260.

184. Olsson, L.; Jerneck, A. Farmers fighting climate change-from victims to agents in subsistence livelihoods. Climate Change 2010, 1, 363-373.

185. Hurni, H.; Herweg, K.; Portner, B.; Liniger, H. Soil Erosion and Conservation in Global Agriculture; Braimoh, A.K., Vlek, P.L.G., Eds.; Springer: Verlag, Netherlands, 2009; pp. 41-71.

186. Cordell, D.; Drangert, J.O.; White, S. The story of phosphorus: Global food security and food for thought. Glob. Environ. Change 2009, 19, 292-305.

187. Obersteiner, M.; Penuelas, J.; Ciais, P.; van der Velde, M.; Janssens, I.A. The phosphorous trilemma. Nat GeoSci 2013, 6, 897-898.

188. Gunders, D. Wasted: How America is losing up to 40 percent of its food from farm to fork to landfill. Available online: http://www.nrdc.org/food/files/wasted-food-ip.pdf (accessed on 22 August 2013).

189. Kummu, M.; de Moel, H.; Porkka, M.; Siebert, S.; Varis, O. Lost food, wasted resources: Global food supply chain losses and their impacts on freshwater, cropland, and fertiliser use. Sci. Total Environ. 2012, 438, 477-489.

190. Johnston, M.; Licker, R.; Foley, J.; Holloway, T.; Mueller, N.D. Closing the gap: Global potential for increasing biofuel production through agricultural intensification. Environ. Res. Lett. 2011, 6, doi:10.1088/1748-9326/6/3/034028.

191. Mueller, N.D.; Gerber, J.S.; Johnston, M.; Ray, D.K.; Ramankutty, N.; Foley, J.A. Closing yield gaps through nutrient and water management. Nature 2012, 490, 254-257.

192. Kayombo, B.; Lal, R. Tillage systems and soil compaction in Africa. Soil Till. Res. 1993, 27, 35-72.

193. Kayombo, B.; Lal, R. Effects of soil compaction by rolling on soil structure and development of maize in no-till and ploughing systems in a tropical alfisol. Soil Till. Res. 1986, 7, 117-134.

194. Mekuria, W.; Veldkamp, E.; Halle, M.; Nyssen, J.; Muys, B. Effectiveness of exclosures to restore degraded soils as a result of overgrazing in Tigray, Ethiopia. J. Arid Environ. 2007, 69, 270-284.

195. Ford, J.D. Vulnerability of inuit food systems to food insecurity as a consequence of climate change: A case study from igloolik, nunavut. Reg. Environ. Change 2009, 9, 83-100.

196. Soussana, J.F.; Fereres, E.; Long, S.P.; Mohren, F.G.M.J.; Pandya-Lorch, R. A European science plan to sustainably increase food security under climate change. Glob. Change Biol. 2012, 18, 3269-3271. 
197. Bows, A.; Dawkins, E.; Gough, C.; Mander, S.; Thom, L.; Thornley, P.; Wood, R. What's Cooking: Adaptation \& Mitigation in the UK Food System; Sustainable Consumption Institute, University of Manchester: Manchester, UK, 2012.

198. Blum, W.E.H.; Eswaran, H. Soils for sustaining global food production. J. Food Sci. 2004, 69, $37-42$.

199. Lal, R.; Safriel, U.; Boer, B. Zero Net Land Degradation. UNCCD Position Paper for Rio+20. Bonn, Germany 2012. http://www.unccd.int/Lists/SiteDocumentLibrary/Rio+20/UNCCD_Policy Brief_ZeroNetLandDegradation.pdf (accessed on 14 November 2011).

200. Gower, J.W.; Palmer, M. Sustainable agricultural development in Sub-Saharan Africa: The case for a paradigm shift in land husbandry. Soil Use Manage. 2008, 24, 92-99.

201. Lal, R. Soil erosion and the global carbon budget. Environ. Int. 2003, 29, 437-450.

202. Montanarella, L.; Vargas, R. Global governance of soil resources as a necessary condition for sustainable development. Curr. Opin. Environ. Sustain. 2012, 4, 559-564.

(C) 2014 by the authors; licensee MDPI, Basel, Switzerland. This article is an open access article distributed under the terms and conditions of the Creative Commons Attribution license (http://creativecommons.org/licenses/by/3.0/). 